\title{
Acoustic ecology of Antarctic pinnipeds
}

\section{Ilse Van Opzeeland ${ }^{1, *}$, Sofie Van Parijs ${ }^{2}$, Horst Bornemann ${ }^{1}$, Stephan Frickenhaus ${ }^{1}$, Lars Kindermann ${ }^{1}$, Holger Klinck ${ }^{3}$, Joachim Plötz ${ }^{1}$, Olaf Boebel ${ }^{1}$}

\author{
${ }^{1}$ Alfred Wegener Institute for Polar and Marine Research, Am alten Hafen 26, 27568 Bremerhaven, Germany \\ ${ }^{2}$ Northeast Fisheries Science Center, NOAA, 166 Water Street, Woods Hole, Massachusetts 02543, USA \\ ${ }^{3}$ Cooperative Institute for Marine Resources Studies, Oregon State University, Hatfield Marine Science Center, \\ 2030 SE Marine Science Drive, Newport, Oregon 97365, USA
}

\begin{abstract}
In aquatic-mating pinnipeds, acoustic communication plays an important role in male competition and mate attraction. Vocal repertoire size and composition during the breeding season varies between species and is presumed to be a product of interspecific differences in sexual selection. In this study, we examine seasonal and diel patterns in acoustic repertoire size, composition and call activity of 4 Antarctic pinniped species: Weddell seal Leptonychotes weddellii, leopard seal Hydrurga leptonyx, Ross seal Ommatophoca rossii and crabeater seal Lobodon carcinophaga. An 11 mo (Jan 2006 - Jan 2007, no recordings Jul and Nov 2006) near-continuous dataset was collected from the Perennial Acoustic Observatory in the Antarctic Ocean (PALAOA) located on the Ekström Iceshelf. The Weddell seal vocal repertoire consisted of 14 call types. Calls were present throughout the year except in February $(11 \mathrm{mo})$, while repertoire composition varied considerably between months. The leopard seal vocal repertoire consisted of 7 call types. Calls were present between October and January $(4 \mathrm{mo})$. All call types were used in a uniform manner throughout the entire call period. The Ross seal vocal repertoire consisted of 5 call types. Ross seal vocalizations were present from December until February (3 mo). Repertoire composition varied little between months. Crabeater seals produced one vocalization type, present from August to December (5 mo). Vocalizations in these species are likely produced in a breeding context. Inter-specific differences in behavioral ecology and interactions with abiotic and biotic environmental factors shape vocal behavior resulting in each species filling its own acoustic ecological niche.
\end{abstract}

KEY WORDS: Weddell seal $\cdot$ Leptonychotes weddellii $\cdot$ Leopard seal $\cdot$ Hydrurga leptonyx $\cdot$ Ross seal · Ommatophoca rossii - Crabeater seal - Lobodon carcinophaga - Vocal repertoire - Vocal activity · Aquatic mating $\cdot$ Acoustic ecology

\section{INTRODUCTION}

In many species acoustic communication plays an important role during the breeding season and serves a function in male-male competition and/or mate attraction (e.g. Ryan 1988, Heller \& Von Helversen 2004, Catchpole \& Slater 2008). Vocal repertoire size during the breeding season varies considerably between species and is presumed to be primarily a product of interspecific differences in factors that drive sexual selection (e.g. Searcy \& Andersson 1986, Read \& Weary 1992). In some species, the occurrence and composition of the vocal repertoire varies over the course of a breeding season, reflecting different stages in the breeding cycle (e.g. Emerson 1992, Roy et al. 1995, Slabbekoorn 2004). For example, female Bornean frog Rana blythi mating vocalizations occur exclusively when females have mature eggs and are involved in courtship (Emerson 1992, Roy et al. 1995). Several species of birds possess 2 acoustically distinct categories of song type that are specialized for use in intersexual and intrasexual communication (e.g. Staicer et al. 1996, Trillo \& Vehrencamp 2005). In banded wrens Thryothorus pleurostictus songs produced by males during the dawn chorus play a role in aggressive male-male interactions, whereas songs 
used during the rest of the day differ in type and structure from the songs produced during the dawn chorus and presumably function solely to advertise the presence and location of a male to a mate (Trillo \& Vehrencamp 2005).

In pinnipeds, the role of vocal behavior during the breeding season differs between land-breeding and aquatic-mating species. On land, the relative rarity of areas suitable for pupping and haul-out leads to the formation of dense female breeding aggregations, which enables males to defend harems and compete with other males for a place within the female breeding group (e.g. Bartholomew 1970). All land-breeding pinnipeds produce in-air vocalizations for the purpose of mother-pup recognition and male-male competition (e.g. Fernández-Juricic et al. 1999, Insley et al. 2003, Tripovich et al. 2008).

In aquatic-mating pinnipeds, females are much more dispersed during the breeding season, causing female movements to be both spatially and temporally less predictable (Van Parijs 2003). As a consequence, females can be less efficiently monopolized by males and therefore males must aim to attract females for the purpose of mating (e.g. Stirling \& Thomas 2003, Harcourt et al. 2007). For those species of aquaticmating pinnipeds where data are available, males are known to retain under water display areas using vocal and dive displays which are thought to function in male-male competition and/or male advertisement to females (see Van Parijs 2003 for a review). In some species, such as harp Pagophilus groenlandicus, Weddell Leptonychotes weddellii and ringed seals Phoca hispida, females are also known to produce underwater vocalizations (e.g. Kunnasranta et al. 1996, Serrano 2001, Oetelaar et al. 2003). However, in most aquaticmating pinniped species only males produce vocalizations associated with mating behavior (see Van Opzeeland et al. 2008 for a review).

The underwater vocal repertoire of aquatic-mating pinnipeds has been described for the majority of species and varies considerably in size between species (Stirling \& Thomas 2003). In a comparative review, Rogers (2003) examined the role of various behavioral and ecological factors on the size of the acoustic repertoire in aquatic-mating seals. Several factors such as the degree of sexual size dimorphism, stability of the pupping substrate, breeding colony density and the degree to which female distribution is predictable to males were shown to influence the size of the vocal repertoire. Based on the acoustic characteristics of the calls, the repertoire size and the function of vocal behavior, Rogers (2003) discriminates 3 groups of vocalization strategies in aquatic-mating seals. (1) The first group comprises hooded Cystophora cristata, grey Halichoerus grypus and crabeater seals Lobodon car- cinophaga. The repertoire of these species is small and consists of short and broadband calls that are thought to be produced by males and have a function in agonistic interaction between males over relatively short distances. (2) Bearded Erignathus barbatus, ribbon Histriophoca fasciata, leopard Hydrurga leptonyx and Ross seals Ommatophoca rossii use stereotyped narrowband calls which are thought to function as signals to rival males and/or potential mates over long distances. These species have a moderately sized vocal repertoire. (3) The third group, consisting of harp, harbour Phoca vitulina, Weddell and ringed seals, has the largest vocal repertoire of the 3 groups, consisting of varied types of sounds that are thought to function in short-range mate attraction and/or territory defense.

As underwater acoustic behavior is in most cases assumed to have a dual function (i.e. male-male competition and mate attraction; e.g. Van Parijs 2003), the proportional usage of different call types could be expected to vary on a seasonal or daily scale reflecting different social contexts in which vocalizations are used. In addition, annual recordings can provide unique insights into how calling behavior is related to other behavioral and ecological variables. Van Parijs et al. (2004) showed that between-year fluctuations in ice cover affect 'territorial' and 'roaming' male bearded seals differently. Roaming males were not heard in years with increased ice cover, whereas territorial males were present during all ice conditions. In harp seals, vocalizations differ structurally during different parts of the year, suggesting that vocal behavior also plays an important role outside the breeding season, such as during herd migration (Serrano \& Miller 2000). Nevertheless, as many aquatic-mating pinnipeds are ice-breeding species and occur at high latitudes, acoustic measurements are often only possible during restricted time periods (e.g. Thomas \& DeMaster 1982, Cleator et al. 1989). In addition, studies on polar species that include recordings over multiple years are rare because of the logistic difficulties and costs of obtaining repeated recordings.

The PerenniAL Acoustic Observatory in the Antarctic Ocean (PALAOA) is a stationary listening station at $70^{\circ} 31^{\prime} \mathrm{S}, 8^{\circ} 13^{\prime} \mathrm{W}$ (Fig. 1), on the Eckström Iceshelf near the eastern Weddell Sea coast. The PALAOA station is autonomous and allows continuous long-term acquisition of acoustic data. Recordings contain vocalizations of 4 Antarctic pinniped species: Weddell, leopard, Ross and crabeater seals. All 4 species differ substantially in their foraging and behavioral ecology as well as the ice type used for breeding and haul-out. Ecological differences between species as well as interspecific interactions might be reflected in acoustic behavior. Information on the presence of a certain species, mediated through their calls, might for example 


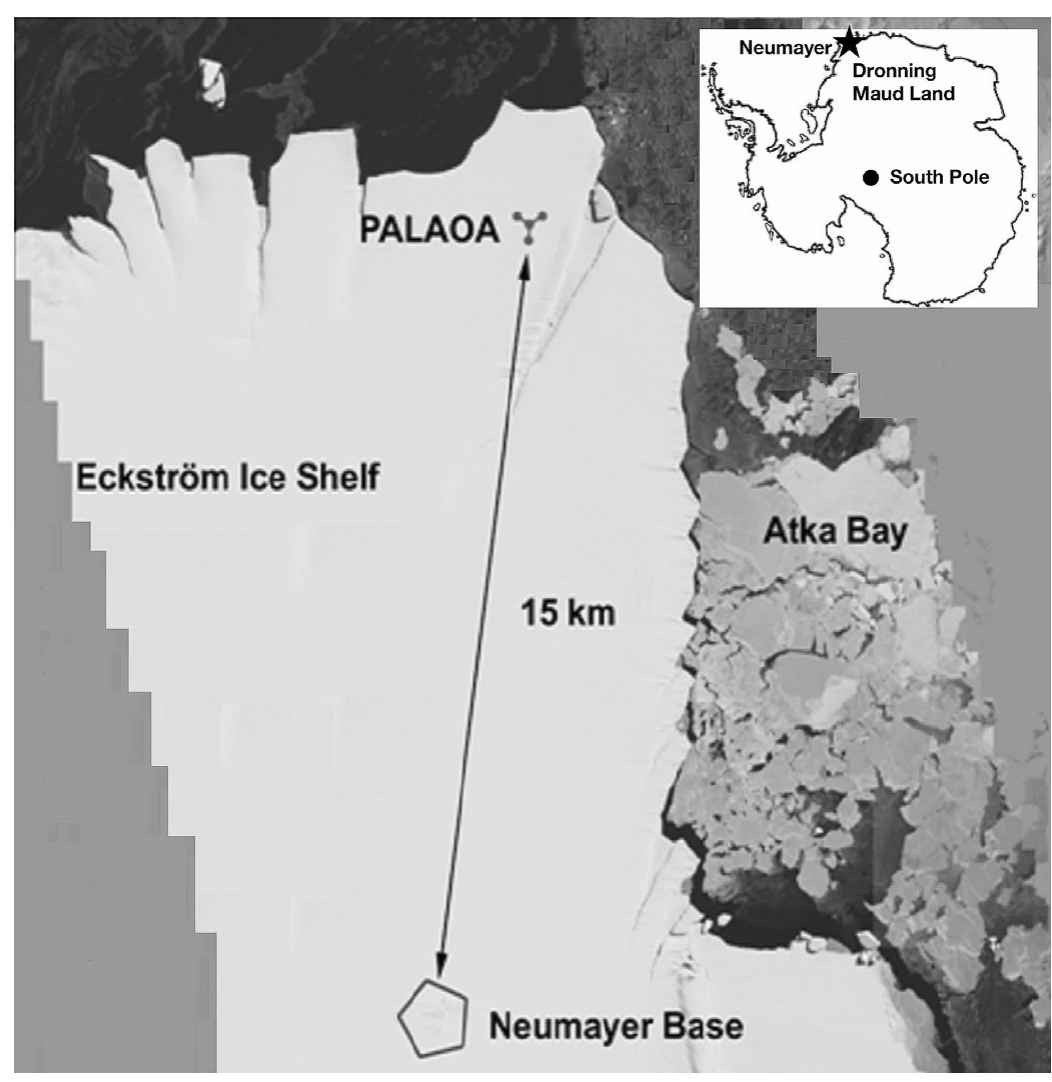

Fig. 1. IKONOS-2 satellite image from March 2004, showing the locations of the German Antarctic station Neumayer Base II and the PALAOA hydroacoustic observatory $\left(70^{\circ} 31^{\prime} \mathrm{S}, 8^{\circ} 13^{\prime} \mathrm{W}\right)$. Inset image top right: Antarctica with the location of Neumayer Base II $(\star)$

be used by and affect behavior of other seal species, e.g. in the case of a predator-prey relationship such as between leopard and crabeater seals.

As acoustic data are collected continuously, the PALAOA data offer the unique opportunity to investigate the calling behavior of these species to explore how acoustic behavior relates to breeding behavior, ecological variables and inter-specific interactions. Improving our knowledge on the fundamental ecology of Antarctic ice-breeding pinnipeds is vital as recent studies have shown that the climate driven changes and anthropogenic alteration of food webs are likely to affect these species (e.g. Learmonth et al. 2006, Cotté \& Guinet 2007, Murphy et al. 2007). Long term acoustic datasets, such as the PALAOA database, require the use of automated detection and classification techniques as manual analysis becomes too time-consuming. However, elementary knowledge of the speciesspecific vocal repertoire and temporal patterns of call type usage is a fundamental requirement needed in order to build a comprehensive understanding of the acoustic behavioral ecology of the species in this area. This study provides a baseline description of the acoustic repertoire of all 4 ice-breeding Antarctic pinniped species - Weddell, Ross, leopard and crabeater seals using an 11 mo data set obtained from the autonomous PALAOA station. Seasonal and diel patterns in the acoustic repertoire are examined from the perspective of multi-species call type variability on a monthly basis.

\section{METHODS}

Acoustic data. Underwater acoustic recordings were obtained from the autonomous PALAOA station. Recordings are made continuously year-round with 2 hydrophones deployed underneath the $100 \mathrm{~m}$ thick floating Antarctic ice shelf through boreholes spaced $300 \mathrm{~m}$ apart (Boebel et al. 2006, Klinck 2008). Water depth below the floating ice shelf is approximately $160 \mathrm{~m}$. Both hydrophones are at a depth of $80 \mathrm{~m}$ below the floating ice shelf. The setup consists of a RESON TC4032 hydrophone (5 Hz to $120 \mathrm{kHz}$, sens. $-170 \mathrm{~dB}$

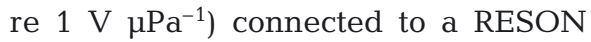
VP2000 amplifier (30 dB gain) and bandpass filter $(10 \mathrm{~Hz}$ to $100 \mathrm{kHz})$, and a RESON TC4033 hydrophone $(1 \mathrm{~Hz}$ to

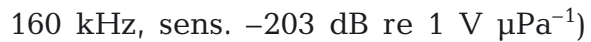
connected to 2 RESON VP2000 amplifiers and bandpass filters. Both hydrophones are galvanically isolated through a Behringer HD400 isolation transformer to avoid picking up electromagnetic interference. The signals are digitized at $48 \mathrm{kHz} / 16$ bit and encoded to a $192 \mathrm{kbit} \mathrm{s}^{-1}$ MP3 stream by a BARIX Instreamer device. The effective bandwidth of the recordings is $10 \mathrm{~Hz}$ to $15 \mathrm{kHz}$, dynamic range $60 \mathrm{~dB}$ to $150 \mathrm{~dB}$ re $1 \mu \mathrm{Pa}$. This stream is transmitted from PALAOA to the German Antarctic Neumayer Station II $(15 \mathrm{~km})$ through wireless LAN. At Neumayer Station II, the stream is segmented into MP3 files of 1 min duration and saved locally. In addition, the audio is compressed to a $24 \mathrm{kbit} \mathrm{s}^{-1}$ OGG-Vorbis stream and transmitted in near-real time from Neumayer to Bremerhaven (Germany) via a $128 \mathrm{kbit} \mathrm{s}^{-1}$ satellite link, from where it is made publicly accessible (www.awi.de/acoustics; see also Kindermann et al. 2008). For this study only the MP3 data were used.

Weddell, Ross, leopard and crabeater seals are known to be present in this region. Every year Weddell seals form breeding groups in austral spring on the fast-ice in Atka Bay, near the PALAOA station (Plötz 
1986). Crabeater seals have also been observed on the pack-ice bordering the ice shelf near PALAOA in austral summer (J. Plötz pers. obs.). Leopard seals and Ross seals have not been observed on the ice in the area near the observatory, but are known to occur in this part of the Weddell Sea (Erickson et al. 1983, Bester \& Odendaal 2000).

Sampling regime. For this study we used data recorded between 4 January 2006 and 30 January 2007 (no recordings for July and November 2006), a total of 11 mo. No data were collected in July due to energy shortages at the PALAOA station. In November 2006 data collection was not possible due to temporary technical failure of the observatory. Within this period, data were sampled for analysis on every fifth day to provide a standardized sample across the year. For every fifth day, 10 consecutive minutes of each hour were analysed with the aim of obtaining a relatively balanced data set for monthly and seasonal comparisons across the year. In cases where it was not possible to sample the fifth day, the preceding day was analyzed instead.

Data were examined in 1 min sound files both aurally and visually using the spectrograms produced by Adobe Audition 2.0. Calls were counted and typeidentified per species by using the overall spectrogram call shape. Catalogues of call types were constructed for each species based on previous studies (Weddell seal: Thomas \& Kuechle 1982, Pahl et al. 1997; leopard seal: Rogers et al. 1995, 1996; Ross seal: Watkins \& Ray 1985, Stacey 2006, Seibert 2007; crabeater seal: Stirling \& Siniff 1979). Calls that were not identifiable from the call type catalogues, but were present twice or more, were assigned a new call type name and added to the call type catalogue. All call types produced by each of the 4 pinniped species differ considerably between species in structure and form. New call types could be attributed to one of the 4 species with certainty based on their overall call shape and were crossvalidated by a second observer.

Data presentation. The number of calls counted per call type for the entire 11 mo data set is presented as a table for each species. The table shows the total number of calls that were counted per call type per month and the proportion of the overall vocal repertoire for each call type. Spectrograms and sound files of all call types described here are presented in Supplements 1 \& 2, available at www.int-res.com/articles/ suppl/m414p267_supp/.

Species-specific proportional call type usage per month was calculated only for those months in which at least 100 calls of this species were counted. This approach focused the analyses on months with peak calling activity. Calculating proportional call type usage allowed comparison of the vocal repertoire com- position between months, independent of the number of samples analysed per month.

Seasonal patterns in overall call activity were obtained by summing all call types and calculating the average number of calls per minute for each day that was sampled.

Diel patterns in call type usage were calculated for each month by averaging the number of calls per call type counted per minute from the 10-min samples for each hour of the day. Calls were assigned to 1-h time windows of the hour in which they occurred (i.e. calls that occurred between 18:00 and 18:59 $\mathrm{h}$ were assigned to $18: 00 \mathrm{~h}$ ). Average diel call type-specific call rates were plotted only for months in which at least 100 calls of the species were counted. The local time at PALAOA is Coordinated Universal Time (UTC) - 33 min. In this study, time is therefore presented in UTC.

Statistical analyses. For all 4 species, changes in acoustic behavior were explored in relation to timing of pupping, mating and moult (phase in breeding cycle). Information on the timing of each of these phases was obtained from the literature (Weddell seal: Lugg 1966, Kaufman et al. 1975, Reijnders et al. 1990; leopard seal: Riedman 1990, Rogers et al. 1996, Southwell et al. 2003; Ross seal: King 1969, Thomas 2002, Southwell et al. 2003; crabeater seal: Siniff et al. 1979, Bengtson 2002, Southwell et al. 2003). Changes in the proportions of call type usage over weeks in relation to the different phases were explored using correspondence analysis (Greenacre 1984) in R version 2.9.2 (R Foundation for Statistical Computing, Vienna, www. R-project.org). Generally, correspondence analysis explores correspondence between the rows and columns of simple 2-way and multi-way tables (Greenacre 1984). For Weddell seals, a correspondence analysis was also performed to compare diel patterns in call type usage between months. For leopard, Ross and crabeater seals the periods during which they were vocally active were too short to compare diel patterns in acoustic behavior between months. See Supplement 3 for the full data set and $\mathrm{R}$ code for the correspondence analyses.

\section{RESULTS}

A total of $10730 \mathrm{~min}$ of PALAOA recordings composed of 107310 -min samples over 11 mo were analyzed. The number of minutes sampled per month ranged between 310 and $1440 \mathrm{~min}$ due to gaps in the otherwise near-continuous data stream (Table 1). However, for all months, more than 300 1-min samples were analysed (average 975 1-min samples per month) and still allowed a balanced comparison of the vocal repertoire composition between months. 
Table 1. Leptonychotes weddellii. Total number of Weddell seal calls per call type (W1-W14 with phonetic description) counted per month between January 2006 and January 2007. n = number of 1-min samples obtained

\begin{tabular}{|c|c|c|c|c|c|c|c|c|c|c|c|c|c|c|}
\hline \multirow{2}{*}{$\begin{array}{l}\text { Call } \\
\text { type } \\
\text { W1 }\end{array}$} & \multirow{2}{*}{$\begin{array}{l}\text { Descr } \\
\text { Trill }\end{array}$} & \multicolumn{13}{|c|}{ 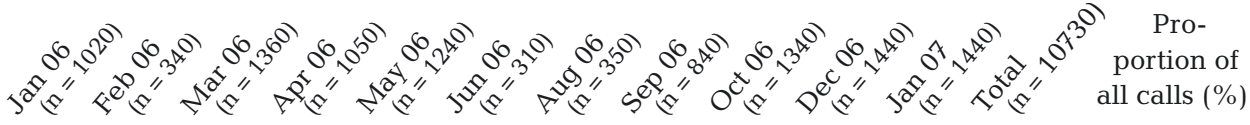 } \\
\hline & & 3 & 0 & 3 & 146 & 1500 & 608 & 574 & 1329 & 2042 & 1949 & 12 & 8166 & 20 \\
\hline W2 & Falling chirps long & 4 & 0 & 2 & 171 & 888 & 397 & 463 & 909 & 1321 & 1054 & 30 & 5239 & 13 \\
\hline W3 & Falling chirps short & 1 & 0 & 5 & 88 & 437 & 133 & 148 & 302 & 395 & 122 & 11 & 1642 & 4 \\
\hline W4 & High-high-low sequence & 0 & 0 & 0 & 56 & 287 & 72 & 54 & 183 & 113 & 2 & 3 & 770 & 2 \\
\hline W5 & Single chirp high & 1 & 0 & 0 & 176 & 1356 & 373 & 519 & 999 & 1062 & 614 & 6 & 5133 & 12 \\
\hline W6 & Single chirp low & 0 & 0 & 0 & 84 & 899 & 417 & 417 & 927 & 1561 & 1205 & 4 & 5514 & 13 \\
\hline W7 & Chirp sequence & 0 & 0 & 0 & 30 & 528 & 169 & 82 & 223 & 214 & 48 & 6 & 1300 & 3 \\
\hline W8 & Oomp & 0 & 0 & 0 & 0 & 43 & 162 & 751 & 1480 & 1765 & 658 & 0 & 5247 & 13 \\
\hline W9 & Falling tone & 0 & 0 & 0 & 80 & 516 & 110 & 152 & 182 & 273 & 36 & 13 & 1362 & 3 \\
\hline W10 & Falling tone short & 0 & 0 & 2 & 43 & 396 & 104 & 27 & 386 & 580 & 331 & 0 & 2059 & 5 \\
\hline W11 & Rising tone & 0 & 0 & 0 & 16 & 51 & 24 & 18 & 60 & 85 & 11 & 2 & 267 & 1 \\
\hline W12 & Flat tone & 0 & 0 & 0 & 9 & 41 & 25 & 11 & 11 & 22 & 19 & 0 & 138 & 0.3 \\
\hline W13 & Warble & 0 & 0 & 0 & 115 & 974 & 500 & 515 & 620 & 931 & 614 & 1 & 4270 & 10 \\
\hline W14 & Pulse sequence & 0 & 0 & 0 & 0 & 77 & 14 & 11 & 36 & 36 & 109 & 0 & 314 & 1 \\
\hline \multicolumn{2}{|c|}{ All calls } & 9 & 0 & 12 & 1014 & 8381 & 3108 & 3932 & 7647 & 10431 & 6799 & 88 & 41421 & 100 \\
\hline
\end{tabular}

\section{Overall call activity}

Weddell seal call activity increased gradually from March to June showing a peak on 1 June 2006 (15 calls $\min ^{-1}$, Fig. 2). Over all days on which Weddell seal vocalizations were present and data was available, the average call rate was $5 \pm 4.27$ calls $\mathrm{min}^{-1}$ (mean \pm average deviation) per minute. Leopard seal call activity showed a peak on 16 December 2006 (9 calls min ${ }^{-1}$ ) and decreased again towards January 2007. The average call activity over all days that leopard seal calls were present is $3 \pm 3.13$ calls $\mathrm{min}^{-1}$. Ross seal call activity increased sharply within the first part of January in both years to a peak on 10 January 2007 (35 calls $\mathrm{min}^{-1}$ ). Average call activity over all days that Ross seal calls were present over January 2006, December 2006 and January 2007 was $11 \pm 8.36$ calls min $^{-1}$. Crabeater call activity showed a peak on 18 October 2006 (4 calls $\mathrm{min}^{-1}$ ) and averaged $1 \pm 1.00$ calls $\mathrm{min}^{-1}$ over all days that crabeater vocalizations were present from August to December 2006. Data from November 2007 from Klinck et al. (2010) show that crabeater call activity is highest during the first half of November, with a peak of 6.5 calls $\mathrm{min}^{-1}$ on 4 November 2007.

Peaks in Weddell, leopard and Ross call activity showed a typical sequential pattern; decreased Weddell seal vocal activity was followed by an increase in leopard seal vocal activity and decreased leopard seal vocal activity was followed by an increase in Ross seal vocal activity. While the sequential pattern seemed present in both January 2006 and 2007, Weddell, leopard and Ross seal call activity was higher in January 2007, compared to call activity in January 2006.

\section{Overall call repertoire}

Weddell seals

For the Weddell seal a total of 41421 calls was counted over the study period. The vocal repertoire consisted of 14 different call types (Fig. S1 in Supplement 1 , Table 1). Over the study period, 6 call types (W1, W2, W5, W6, W8, W13) each contributed more than $10 \%$ to the total number of Weddell seal calls, while the other 8 call types (W3, W4, W7, W9, W10, W11, W12, W14) occurred less frequently, ranging between 0.3 to $5 \%$ of the total number of calls. Call type W4 has not been described previously, whereas the other call types have been described in numerous previous studies (Thomas \& Kuechle 1982, Pahl et al. 1997, Moors \& Terhune 2004, Terhune \& Dell'Apa 2006). Call type W4 was associated with Weddell seals based on its acoustic similarity to call type W2 and W3 and similar pattern of occurrence.

\section{Leopard seals}

A total of 13687 calls was counted for leopard seals. The leopard seal vocal repertoire consisted of 7 different call types (Fig. S2 in Supplement 1, Table 2). Call type $\mathrm{L} 6$ contributed more than $60 \%$ to the total number of calls. The other call types occurred less frequently, ranging between 3 and $10 \%$ of the total number of calls. All leopard seal call types recorded by PALAOA have been described previously (Stirling \& Siniff 1979, Rogers et al. 1995, 1996). Stirling \& Siniff (1979) and 


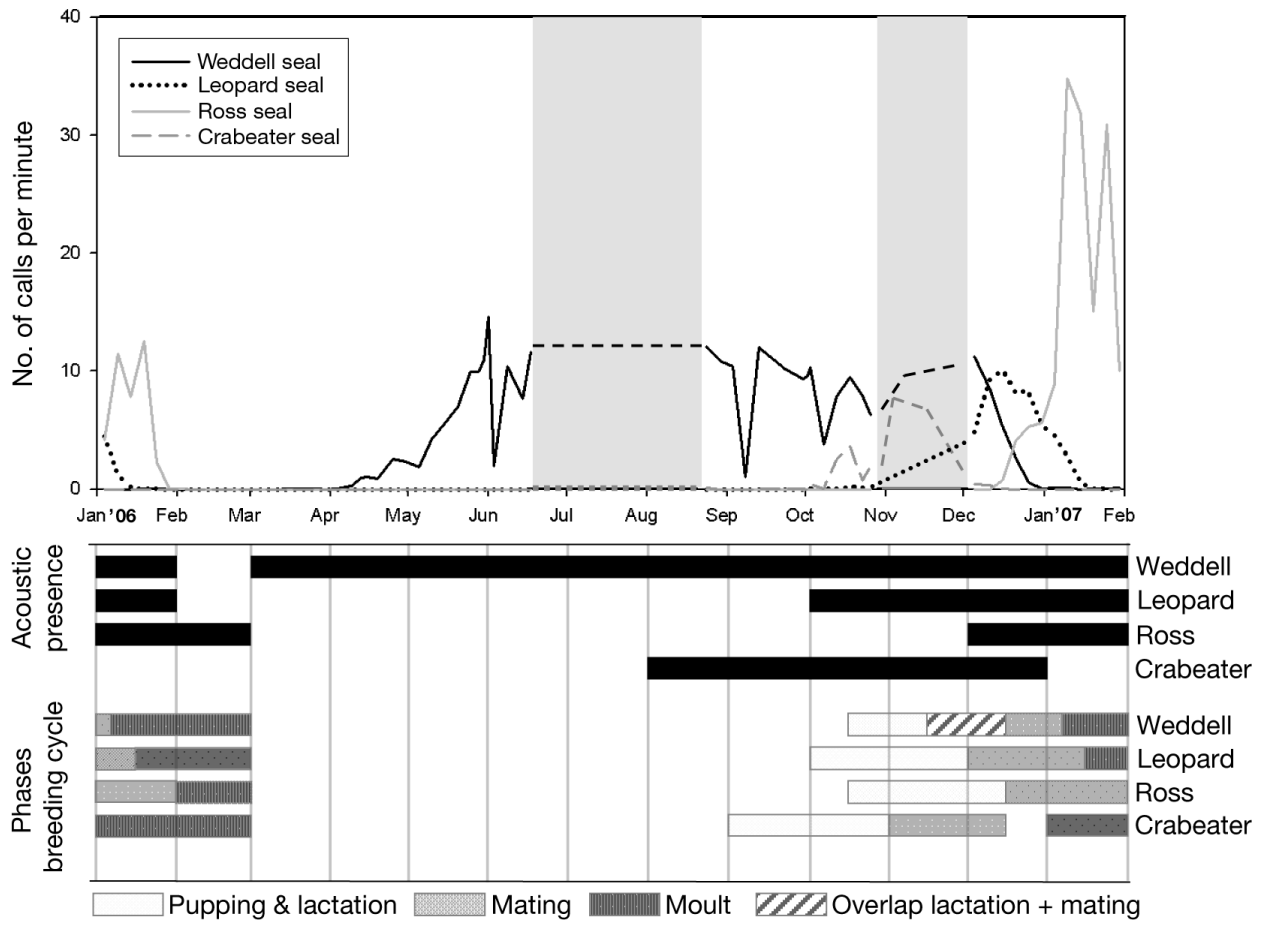

Fig. 2. Overall call activity for all 4 seal species in the period January 2006 to February 2007. The average number of calls per minute is calculated per day for all days that were included in the analyses. Call activity in the grey shaded areas represents counts of 1-min PALAOA samples from 2007 as recordings from these months were not available from 2006 (every fifth day, 2 min each sixth hour). For crabeater seals, call activity in November was based on PALAOA data from 2007 from Klinck et al. (2010). The lower schema shows acoustic presence for all 4 seal species and the timing of the pupping, mating and moulting periods for Weddell, leopard, Ross and crabeater seals based on literature (see 'Methods: Statistical analysis' for sources)
Rogers et al. (1996) discriminate 2 subtypes within call type L7: the 'mid double trill' and the 'mid single trill'. In this study all mid trills were lumped into call type L7. Both mid trill types are shown in Fig. S2.

\section{Ross seals}

A total of 42231 calls was counted for Ross seals. The vocal repertoire consisted of 5 call types (Fig. S3 in Supplement 1, Table 3). Three call types (R1, R2 and R3) each contributed more than $20 \%$ to the total number of calls. Call types R4 and R5 occurred often in association; R4 is a tonal call, while R5 is a broadband sound (Fig. S3). These 2 call types occurred less frequently compared to the other call types, each contributing $6 \%$ to the total number of calls. Ross seal call types R1, R2, R3 and R5 have been described previously (Watkins \& Schevill 1968, Stacey 2006, Gedamke \& Robinson 2010). So far call type R4 has only been found present in the PALAOA recordings (Seibert 2007).

\section{Crabeater seals}

A total of 2126 crabeater seal moans were counted over the study period. For crabeater seals, we identified one call type in the PALAOA recordings, the moan vocalization (C1). The moan vocalization has been described in previous studies (Stirling \& Siniff 1979, Thomas \& DeMaster 1982). Klinck et al. (2010) identified another variety of this crabeater seal call type, the high moan. Both varieties of crabeater moans are depicted in Supplement 1, Fig. S4. However, in this study we did not discriminate between high and low moans and lumped all crabeater vocalizations into call type C1.

\section{Monthly proportional call type usage}

\section{Weddell seals}

Weddell seal calls were present in all months of 2006 for which data were available, except February (Fig. 2). Preliminary inspection of data from the following year (2007) showed that all call types were also present in July and November, the months for which no data were available in 2006. For the remaining months in 2006, the composition of the Weddell seal vocal repertoire varied and not all call types occurred in all months (Table 1). Call types W1, W2 and W3 were present in January 2006 and from March 2006 to January 2007. Call types W4, W5, W6, W7, W9, W11 and W13 occurred from April 2006 to January 2007, although W5 also occurred once in January 2006. Call type W12 was present from April to December. Call type W10 was present from March to December, whereas call types W8 and W14 occurred only between May and December. 
Table 2. Hydrurga leptonyx. Total number of leopard seal calls per call type (L1-L7) counted per month between January 2006 and January 2007. $\mathrm{n}$ = number of 1 -min samples obtained

\begin{tabular}{|c|c|c|c|c|c|c|c|c|c|c|c|c|c|c|}
\hline \multirow{2}{*}{$\begin{array}{l}\text { Call } \\
\text { type }\end{array}$} & Description & \multicolumn{13}{|c|}{ 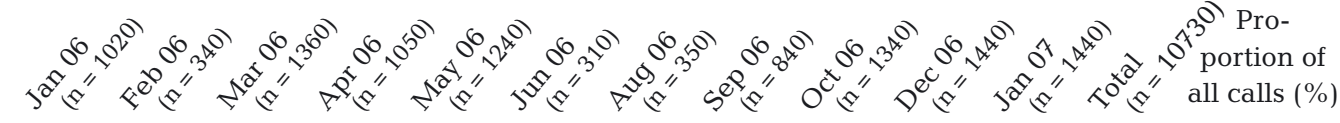 } \\
\hline & Low ascending trill & 27 & 0 & 0 & 0 & 0 & 0 & 0 & 0 & 1 & 601 & 54 & 683 & 5 \\
\hline L2 & Low descending trill & 38 & 0 & 0 & 0 & 0 & 0 & 0 & 0 & 3 & 587 & 84 & 712 & 5 \\
\hline L3 & High double trill & 39 & 0 & 0 & 0 & 0 & 0 & 0 & 0 & 5 & 1004 & 118 & 1166 & 9 \\
\hline L6 & Low double trill & 425 & 0 & 0 & 0 & 0 & 0 & 0 & 0 & 64 & 6578 & 1420 & 8487 & 62 \\
\hline L7 & Mid trill & 31 & 0 & 0 & 0 & 0 & 0 & 0 & 0 & 6 & 692 & 60 & 789 & 6 \\
\hline \multicolumn{2}{|c|}{ All calls } & 626 & 0 & 0 & 0 & 0 & 0 & 0 & 0 & 86 & 11075 & 1900 & 13687 & 100 \\
\hline
\end{tabular}

Proportional call type usage per month was calculated from April to December (Fig. 3). In April, call types W2 and W5 formed the largest part of the vocal repertoire, followed by W1 and W13. In May and June W1 was the most predominant call type, followed by W5 and W13, respectively. W8 was the most predominant call type in August and September, followed by W1 in both months. In October and December, proportional usage was highest for call type W1, followed by W8 and W6, respectively.

When the proportional composition of the repertoire was compared between months, the proportional usage of call types W1, W7, W10, W11, W12 and W14 was relatively constant from April to December. Proportional usage of call types W2 and W3 decreased towards December, although the proportional usage of call type W2 increased again to $16 \%$ in December. Call types W4, W5 and W9 decreased in proportional usage from April to December. W13 showed a gradual decrease in proportional usage from June towards the pupping and mating period (October to December), whereas the proportional usage of W6 increased towards December. W8 showed a gradual increase in usage towards a peak in September $(19 \%)$, after which proportional usage decreased again.
Furthermore, call types W4, W6, W7, W9, W11, and W13 were present in the recordings from January 2007 , whereas these call types were not present in the January 2006 recordings (Table 1 ).

Fig. 4a shows the dissimilarity of Weddell seal repertoire composition based on a correspondence analysis of weekly call-type profiles. Call types W14 and W8 were clearly separated from the rest. The ordination in weeks (Fig. 4b) shows 3 groups of consecutive weeks (ellipses): winter (Weeks 16 to 24, W), spring (Weeks 34 to $43, \mathrm{Sp}$ ), and beginning of summer (S). In addition, the weekly call repertoire composition was separated through correspondence analysis according to the different phases, showing similarity in call repertoire composition between the mating phase (Ma) and the Lactation and Mating phase (LM) (Fig. 5a). Repertoire composition during the moult phase (Mo) was separated by the first discriminant axis, while Ma and LM were separated by the second discriminant axis ( $y$ axis). The contribution of the call types (Fig. 5b) showed that call type W14 characterized the Ma and LM period, whereas Mo was characterized by an increased usage of W11 and reduction in usage of call type W12.

Table 3. Ommatophoca rossi. Total number of Ross seal calls per call type (R1-R5) counted per month between January 2006 and January 2007. $\mathrm{n}=$ number of 1-min samples obtained

\begin{tabular}{|c|c|c|c|c|c|c|c|c|c|c|c|c|c|c|}
\hline $\begin{array}{l}\text { Call } \\
\text { type }\end{array}$ & Description & \multicolumn{6}{|c|}{ 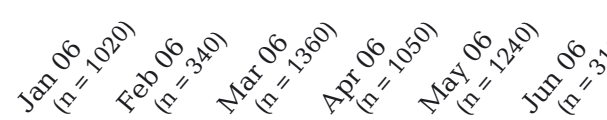 } & 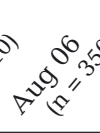 & 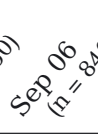 & \multicolumn{3}{|c|}{ 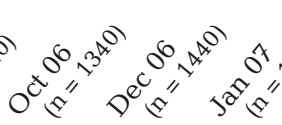 } & $x_{0}$ & $\begin{array}{l}\hat{x}^{3} \text { Pro- } \\
\text { portion of } \\
\text { all calls }(\%)\end{array}$ \\
\hline R1 & High siren call & 2149 & 7 & 0 & 0 & 0 & 0 & 0 & 0 & 0 & 564 & 9001 & 11721 & 28 \\
\hline R2 & Mid siren call & 1539 & 0 & 0 & 0 & 0 & 0 & 0 & 0 & 0 & 833 & 6477 & 8849 & 21 \\
\hline R3 & Low siren call & 2060 & 0 & 0 & 0 & 0 & 0 & 0 & 0 & 0 & 2259 & 12479 & 16798 & 40 \\
\hline R4 & Tonal element & 634 & 0 & 0 & 0 & 0 & 0 & 0 & 0 & 0 & 25 & 1692 & 2351 & 6 \\
\hline R5 & $\begin{array}{c}\text { Broadband } \\
\text { element }\end{array}$ & 520 & 0 & 0 & 0 & 0 & 0 & 0 & 0 & 0 & 73 & 1919 & 2512 & 6 \\
\hline \multicolumn{2}{|c|}{ All calls } & 6902 & 7 & 0 & 0 & 0 & 0 & 0 & 0 & 0 & 3754 & 31568 & 42231 & 100 \\
\hline
\end{tabular}




\section{Leopard seals}

Leopard seal calls occur between October and January (Table 2). Preliminary inspection of PALAOA data from the following year showed that all leopard seal call types were present in November 2007, which was the month for which no data were available in 2006.

Call types L1, L2, L3, L5, L6 and L7 occurred from October to January, whereas L4 occurred in January and December, but did not occur in October. Proportional call type usage per month was calculated for January 2006, December 2006 and January 2007 (Fig. 6). Call type L6 was the most predominant call type in all 3 months. The proportional composition of the repertoire was relatively similar between December and January and did not differ largely between January 2006 and January 2007.
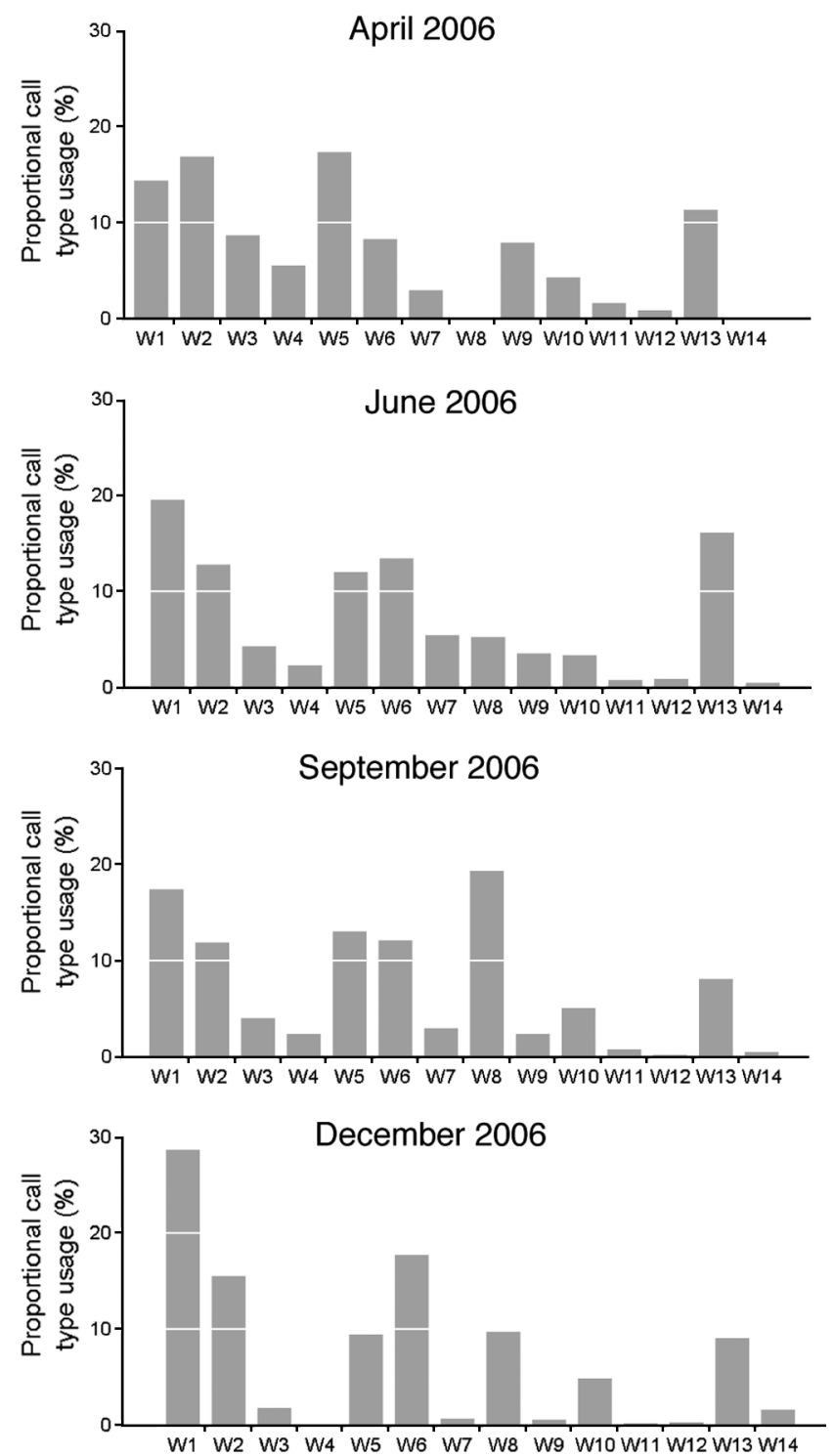

The correspondence analysis showed that leopard seal call repertoire composition differed between the pupping and lactation phase (PL) and moult phase (Mo) and were separated on the second discriminant axis ( $y$-axis, Fig. S5a in Supplement 4). PL and Mo were characterized by a decrease in usage of call type L2 and L4, respectively (Fig. S5b).

\section{Ross seals}

Ross seal calls occurred between December and February (Table 3). The first Ross seal calls were recorded on December 16, 2006. Preliminary inspection of PALAOA data from the following year showed that no Ross seal calls were present in November 2007 (Seibert 2007), suggesting that Ross seal vocal activity
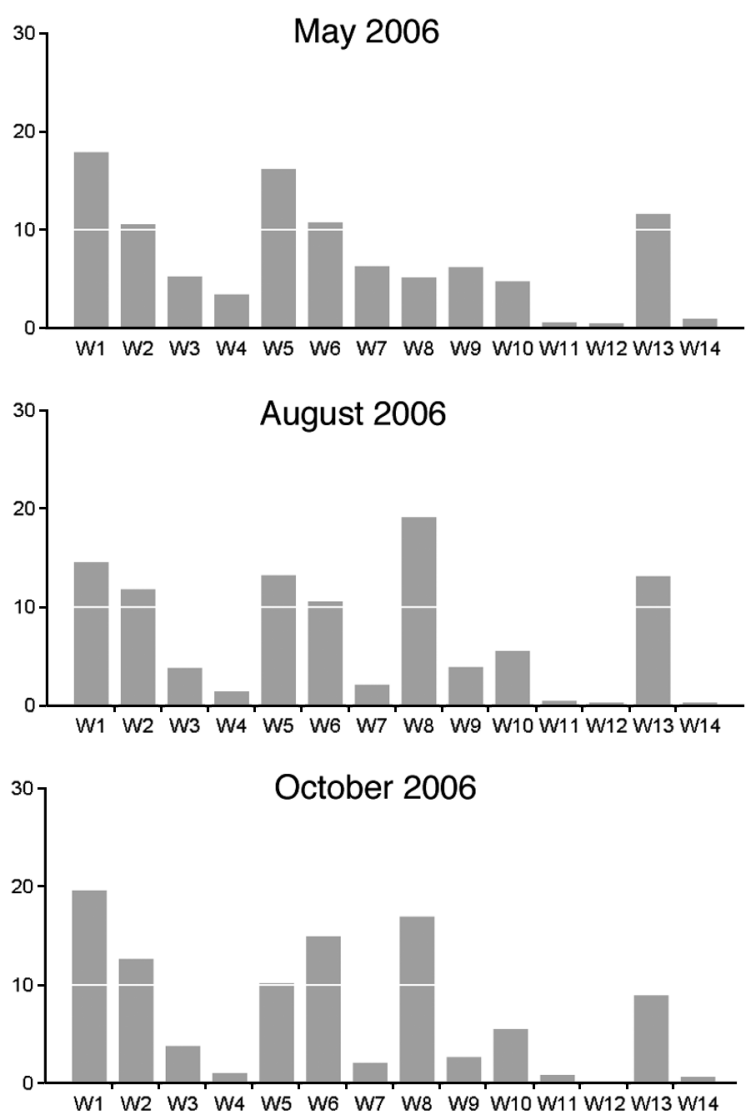

Fig. 3. Leptonychotes weddellii. Weddell seal proportional call type (W1-W14) usage per month for months in which at least 100 Weddell seal calls were recorded 

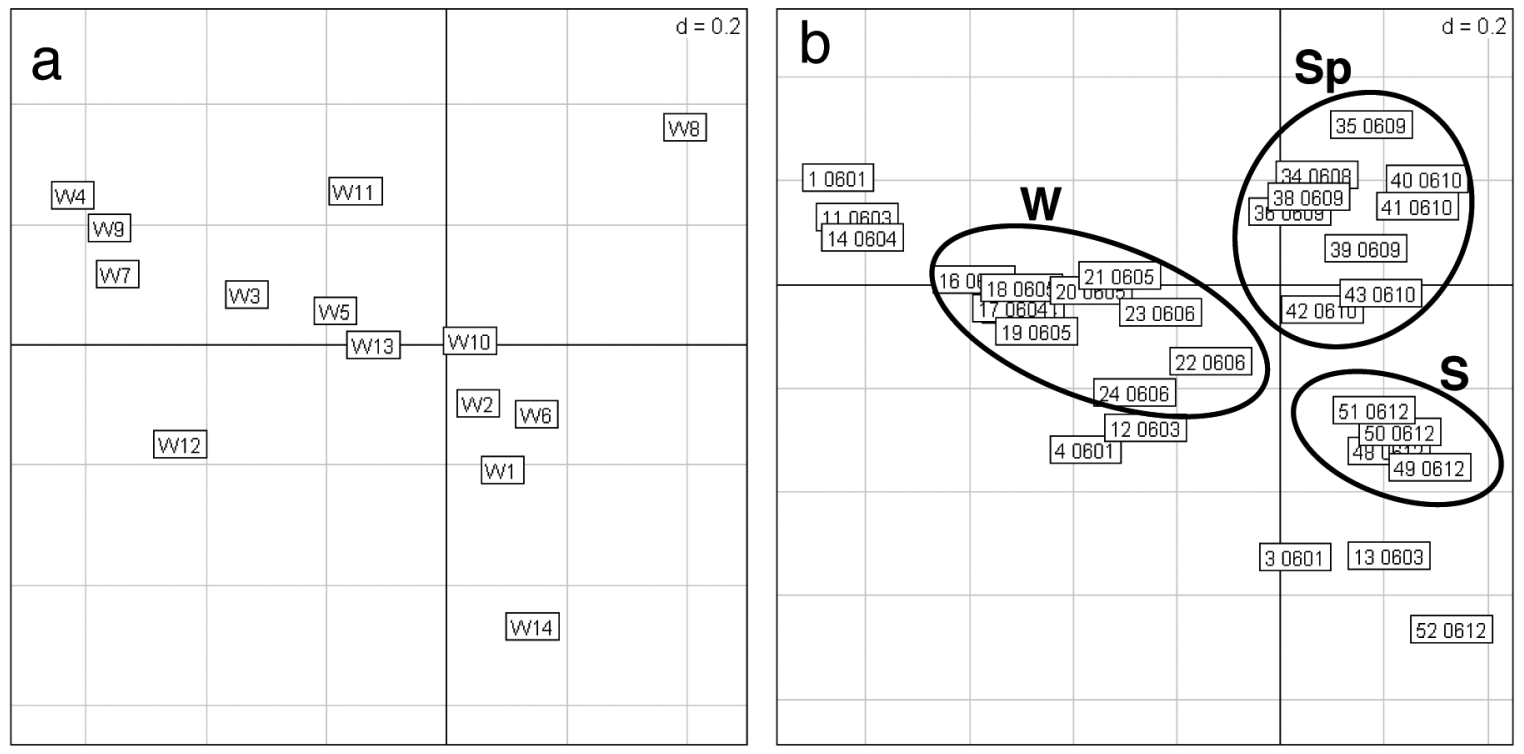

Fig. 4. 2D-Correspondence analysis call-type counts per week for Weddell seals. (a) Mapping of call-types, showing W8 and W14 as distinct from the rest. (b) Ordination of the weeks (format WW YYMM). Clusters of consecutive weeks are visualized by ellipses, corresponding to the seasons (W: winter; Sp: spring; S: summer)

starts in December. Of all call types, only R1 occurred in February. Proportional call type usage per month was calculated for January 2006, December 2006 and January 2007 (Fig. 7). Call type R1 was the most predominant call type in January 2006, followed by call type R3. In December 2006 and January 2007, call type R3 had the highest proportional usage, followed by R2 and R1, respectively. Call types R4 and R5 occurred in similar, relatively small proportions $(<10 \%)$ and were used most often in January. All call types showed a similar pattern in proportional usage in January 2006 and 2007, although call type R3 formed a larger part of the vocal repertoire in January 2007 compared to January 2006.

Ross seal calls were only recorded during the mating phase and therefore discrimination of call repertoire composition according to phase was not possible. The correspondence analysis showed that call repertoire composition varied little over the period that Ross seal calls were recorded (Fig. S6a in Supplement 4). The structure of call type usage showed that the first week during which Ross seal calls were recorded was characterized by increased usage of call type R3 (Fig. S6b).

\section{Crabeater seals}

Crabeater seal C1 calls were present between August and December 2006 (Fig. 2). Data from the following year showed that crabeater calls were also present and that call activity actually peaked in No-

Fig. 5. Discriminating correspondence analysis of Weddell seal call-type profiles by weeks. (a) Plot of first 2 discriminant scores, with groups captured in ellipses. Mo: Moult; Ma: mating; LM: overlap of lactation and mating; PL: pupping and lactation; O: other weeks. (b) Plot of structure of call types: call type W14 dominates separation on the second discriminant ( $y$-axis); call type W12 dominates the separation on the first discriminant ( $x$-axis)
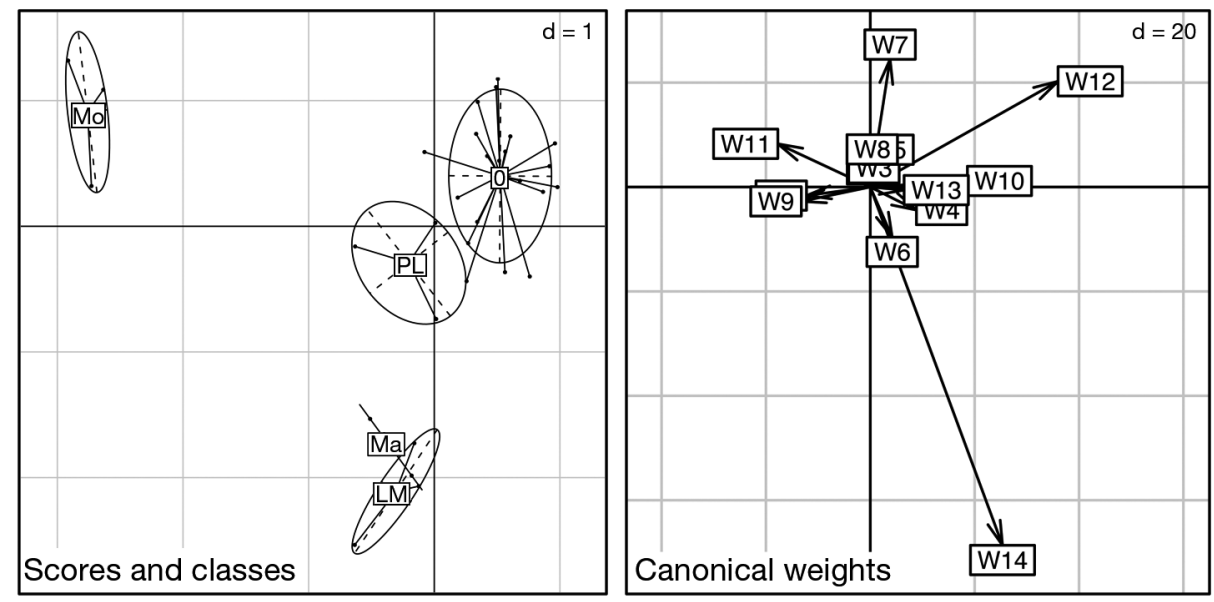

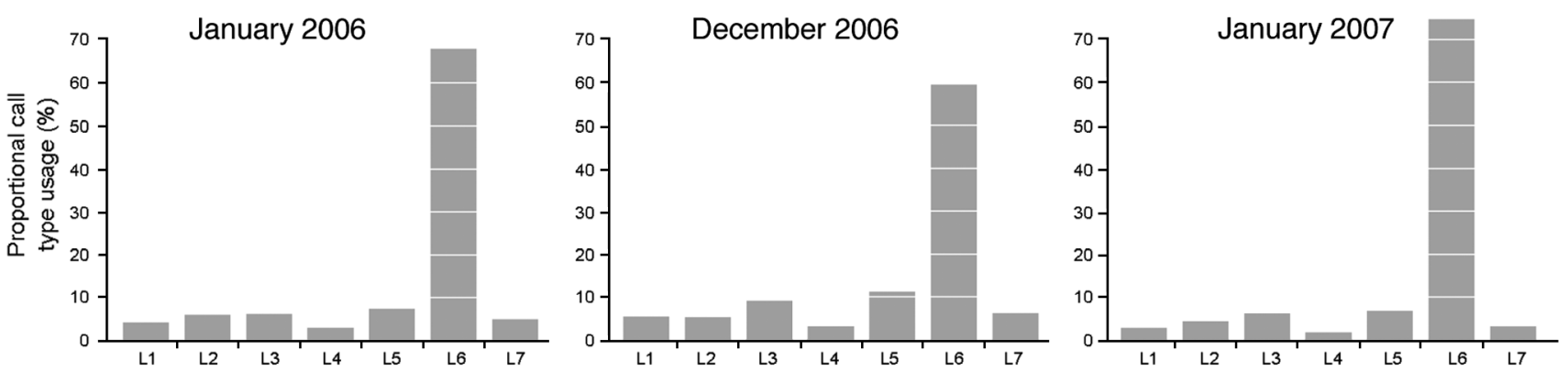

Fig. 6. Hydrurga leptonyx. Leopard seal proportional call type (L1-L7) usage per month for months during which at least 100 leopard seal calls were recorded

vember 2007. For 2006, the number of calls recorded by PALAOA was highest in October (Fig. 8).

\section{Diel patterns in call type usage}

\section{Weddell seal}

To determine the Weddell seal diel pattern in call type usage, only call types that contributed more than $10 \%$ to the vocal repertoire were used (Call types W1, W2, W5, W6, W8 and W13). This approach excludes all call types that were rarely used when call type usage is compared on a diel scale. For all call types, the average number of calls per hour in April 2006 showed little variation over the day, with only a small peak occurring around 18:00 h UTC (Fig. 9a). In May, W1 was the most predominant call type. Overall the number of calls was highest around 7:00 and 16:00 h UTC, whereas there was only little calling activity between 10:00 and 14:00 h UTC. Due to a temporary energy shortage at the PALAOA station, no data were collected between 7:00 and 11:00, between 18:00 and 20:00 and between 22:00 and 23:00 h UTC in June 2006. Despite these gaps, the diel calling pattern in June resembled the 2-peak pattern in May 2006, but with call type W1 showing a sharp peak of $2 \pm 0.64$ calls min $^{-1}$ (mean \pm average deviation) around 16:00 h UTC. In August and September 2006 W8 was the most predominant call type, with an average of $2 \pm 0.77$ and $2 \pm 0.45$ calls $\mathrm{min}^{-1} \mathrm{~h}^{-1}$ respectively. In August, the overall Weddell seal call activity showed peaks between 4:00 and 7:00 h UTC and 18:00 and 20:00 h UTC. In September the bimodal pattern in vocal activity was still visible (Fig. 9b). In October and December 2006 W1 was the most frequent call type, with an average of $2 \pm 0.21$ and $1 \pm 0.22$ calls $\mathrm{min}^{-1} \mathrm{~h}^{-1}$ respectively. In these 2 months, the average number of calls min $^{-1} \mathrm{~h}^{-1}$ showed little variation over the day. When Weddell seal call usage patterns were compared for single days within each month, these generally reflected the average monthly pattern.

The biphasic pattern in Weddell seal diel call activity in May (Fig. 9a) can be partly resolved by a correspondence analysis. Fig. 10a shows the dissimilarity of W5, W8 and W9 from the other call types. The ordination of hours is shown in Fig. 10b and allows identification of the quiet phase between 10:00 and 12:00 h (first discriminant axis, $x$-axis). Vocal repertoire composition during the remaining time is grouped in 2 periods: morning+afternoon (upper part, 05:00 to 18:00 h) and evening+night (lower part, 19:00 to 04:00 h).

\section{Leopard seal}

Fig. 11 shows the diel calling pattern in January 2006, with 2 distinct peaks in L6 calling activity around
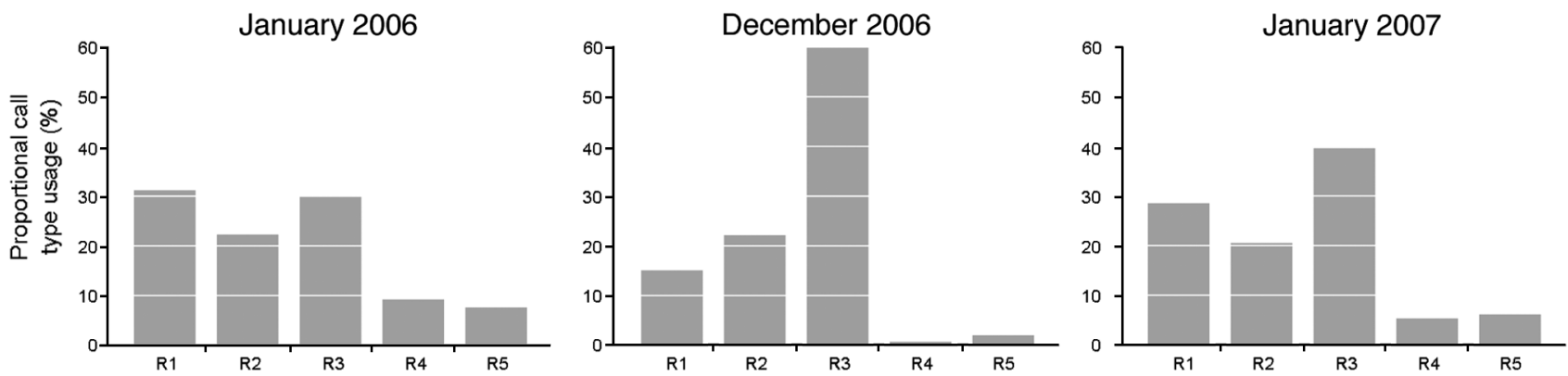

Fig. 7. Ommatophoca rossi. Ross seal proportional call type (R1-R5) usage per month for months in which at least 100 Ross seal calls were recorded 


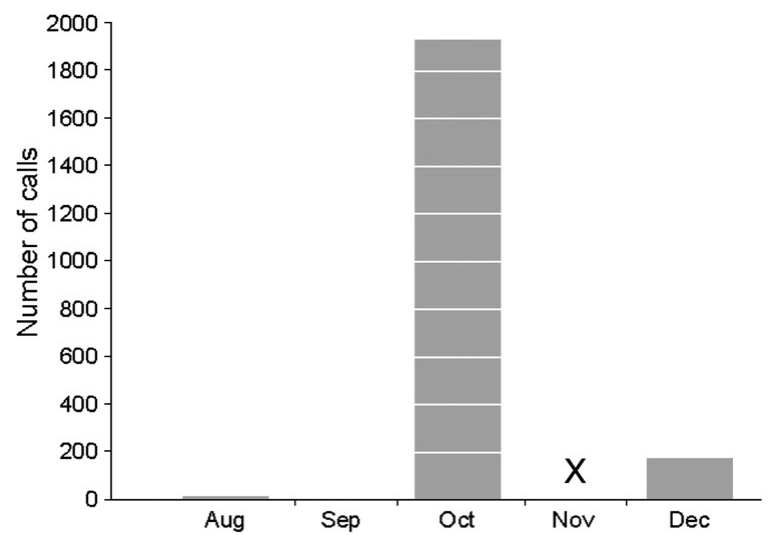

Fig. 8. Lobodon carcinophaga. Number of crabeater seal calls (type C1) recorded for all months in which crabeater calls were recorded, August to December 2006
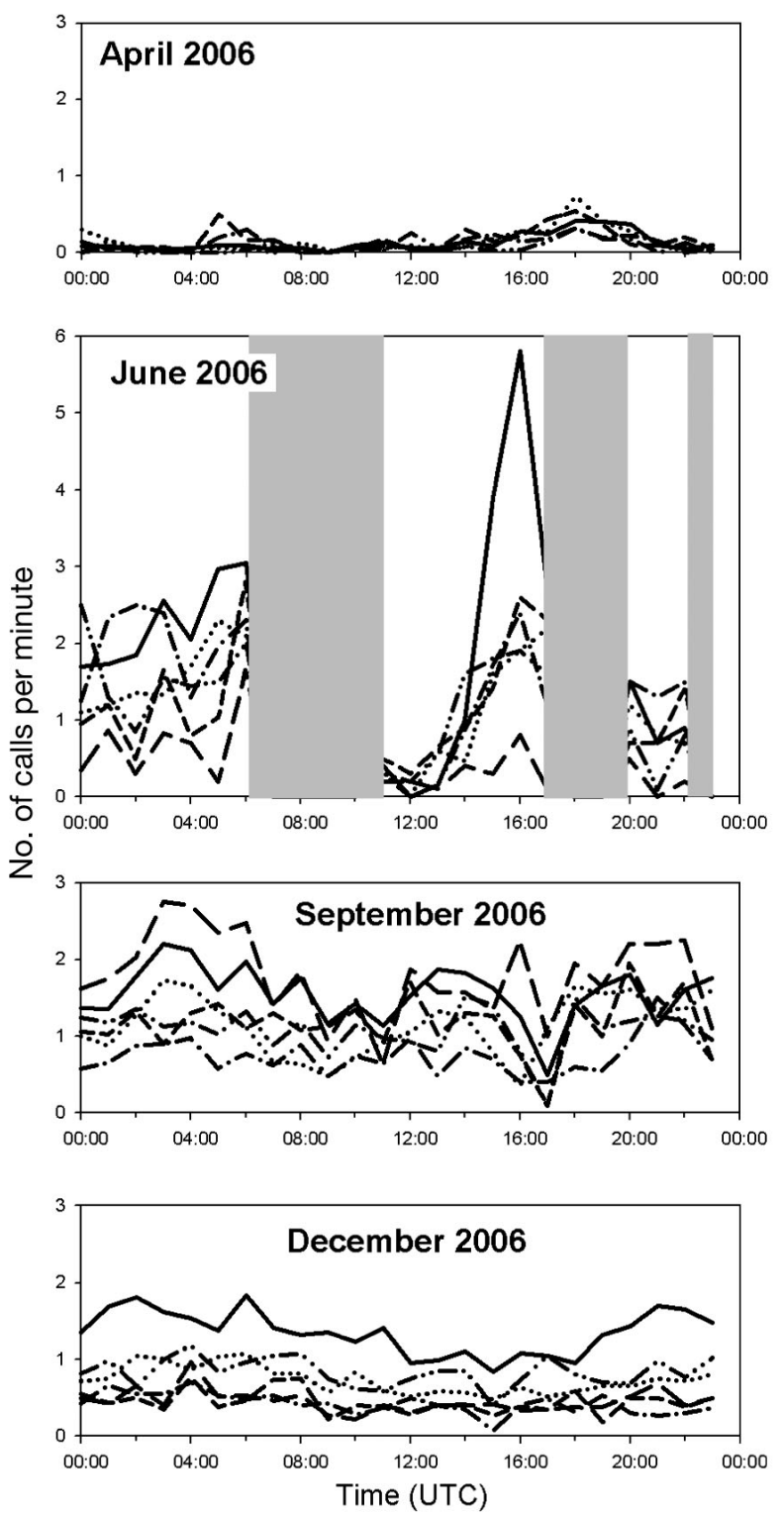

8:00 ( $1 \pm 0.98$ calls min $^{-1}$, mean \pm average deviation $)$ and 20:00 h UTC $\left(1 \pm 1.13\right.$ calls $\left.\mathrm{min}^{-1}\right)$. The call rates of the other call types also increased slightly during these hours, however, call rates were much lower compared to call type L6. In December, the number of L6 calls increased to $5 \pm 0.33$ calls $\mathrm{min}^{-1} \mathrm{~h}^{-1}$ and remained constant throughout the day. Call rates of the other call types also increased compared to January 2006 and 2007 and remained fairly constant throughout the day, ranging from 0.3 to 0.9 calls $\mathrm{min}^{-1} \mathrm{~h}^{-1}$. The average number of L6 calls was $1 \pm 0.25$ calls $\mathrm{min}^{-1} \mathrm{~h}^{-1}$ in January 2007, and $0.4 \pm 0.22$ calls $\mathrm{min}^{-1} \mathrm{~h}^{-1}$ in January 2006 . In contrast to the 2-peak pattern in call activity in January 2006, calling activity showed a 1-peak pattern in January 2007 with the peak occurring around midnight. Leopard seal call usage for single days within
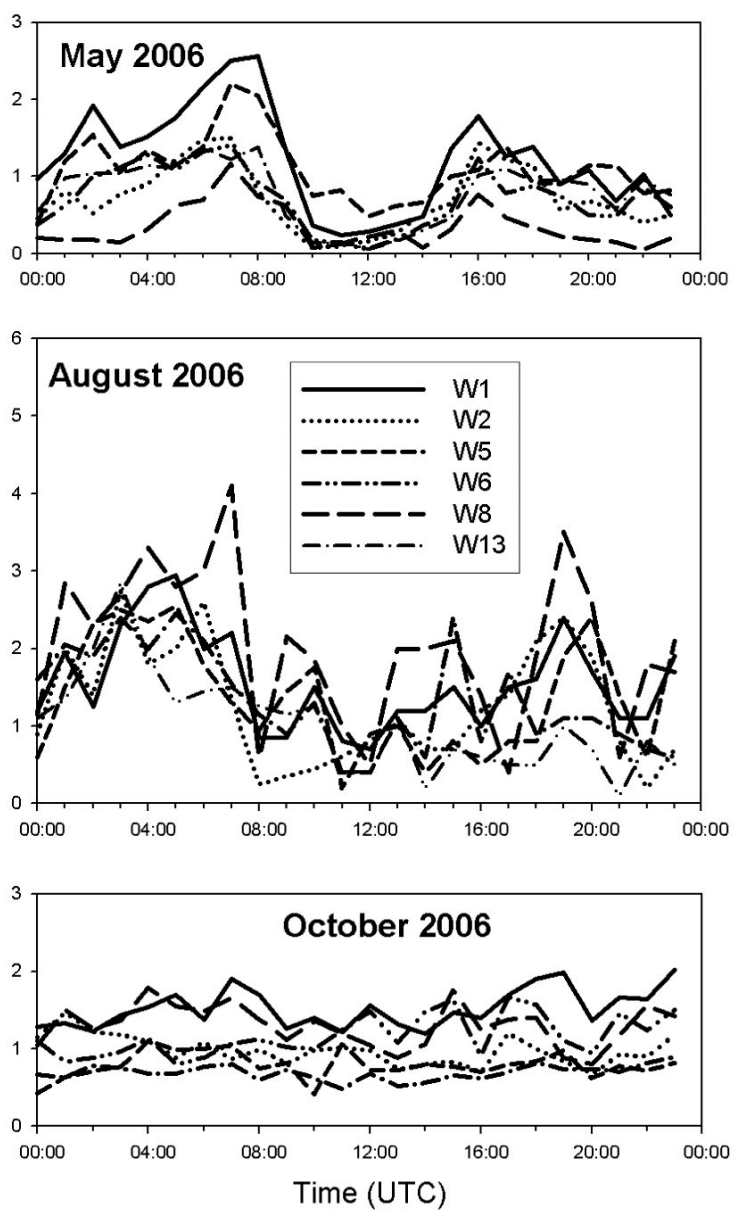

Fig. 9. Leptonychotes weddellii. Diel pattern of Weddell seal call type usage for call types W1, W2, W5, W6, W8, W13 for months in which at least 100 Weddell seal calls were recorded. Grey areas indicate discontinuities in the data stream. Time is presented in Coordinated Universal Time (UTC); local time at PALAOA is UTC - $33 \mathrm{~min}$ 
each month showed relatively comparable patterns and reflected the monthly average patterns in call type usage and activity.

\section{Ross seal}

The diel calling pattern in January 2006 shows an increase in the number of calls for all call types between 12:00 and 19:00 h UTC (Fig. 12). R1 was the predominant call type in January 2006, with $2 \pm 0.82$ (mean \pm average deviation) $\mathrm{R} 1$ calls $\mathrm{min}^{-1} \mathrm{~h}^{-1}$ in that month. In December, call rates increased during the second half of the day, with R3 being the most dominant call type in that month $\left(2 \pm 0.69\right.$ calls min $\left.^{-1} \mathrm{~h}^{-1}\right)$. In January 2007, R3 was also the predominant call type $\left(9 \pm 0.97\right.$ calls min $\left.^{-1} \mathrm{~h}^{-1}\right)$. Overall call rates in January 2007 were higher compared to January 2006 ( $7 \pm 1.84$ and $22 \pm 2.28$ calls min $^{-1} \mathrm{~h}^{-1}$ for January 2006 and 2007 respectively). In January 2007, call rates were relatively constant over the day, with a short period of decreased call activity around 6:00 h UTC. However, when Ross seal call activity was compared between single days within a month, patterns in call activity varied considerably between days in January 2006 and January 2007. In addition, call types R1 and R3 were the most predominant call types when single days in January 2006 and January 2007 were compared (Fig. 13). In December the pattern in Ross seal call activity showed a more consistent pattern when single days were compared, with a period of low call activity occurring between 00:00 and 9:00 h UTC. Call type R3 was the most predominant call type on all days in December.

\section{Crabeater seal}

In October 2006, crabeater seal calling activity increased sharply between 16:00 and 19:00 h UTC and remained around 4 calls $\mathrm{min}^{-1} \mathrm{~h}^{-1}$ until 23:00 h UTC (Fig. 14). The average number of calls in October was $1 \pm 0.94$ (mean \pm average deviation) calls $\min ^{-1} \mathrm{~h}^{-1}$. Fig. $12 \mathrm{~b}$ shows considerable variability in the call activity pattern when comparing 2 separate days in October. In December 2006, the average number of calls in December was $0.1 \pm 0.1$ calls min $^{-1} \mathrm{~h}^{-1}$. The diel calling pattern showed 2 small peaks; one around 02:00 and one around 20:00 h UTC. This pattern is consistent with the pattern observed for separated days in December (Fig. 15).

\section{DISCUSSION}

The results of this study show that Weddell, leopard, Ross and crabeater seals exhibit substantial interspecific variation in acoustic behavior, i.e. in temporal patterns of vocal activity, vocal repertoire size and composition. Variation in acoustic behavior can reflect inter-specific differences in the acoustic ecology of the species, the relationship between the organism and the environment mediated through sound. In analogy to ecology, each species might be thought of as filling its own acoustic ecological niche, shaped by internal and external factors and interactions between both (Fig. 16; Van Opzeeland 2010). Vocalizations are produced in a breeding context and consequently differences in behavioral ecology between species, such as distribution and mating system, are likely to shape
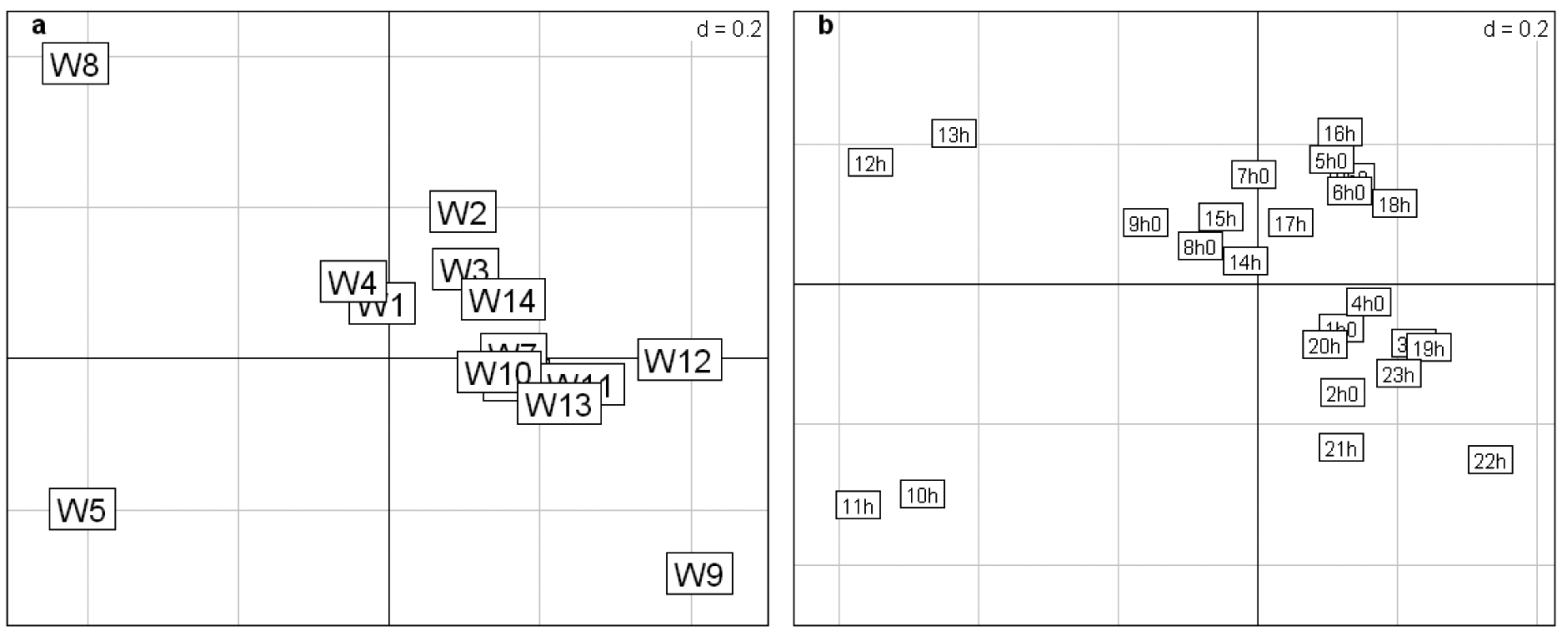

Fig. 10. 2D-correspondence analysis of hourly call-type counts of Weddell seals in May 2006. (a) Mapping of call types, showing W5, W8 and W9 as distinct from the rest. (b) Ordination of the hour bins, showing strong separation of the call patterns during 10:00-11:59 $\mathrm{h}$ and 12:00-13:59 $\mathrm{h}$ from the rest. Repertoire for the remaining time is grouped in two: lower part: evening and night (19:00-04:00 h); upper part: morning and afternoon (05:00-18:00 h) 

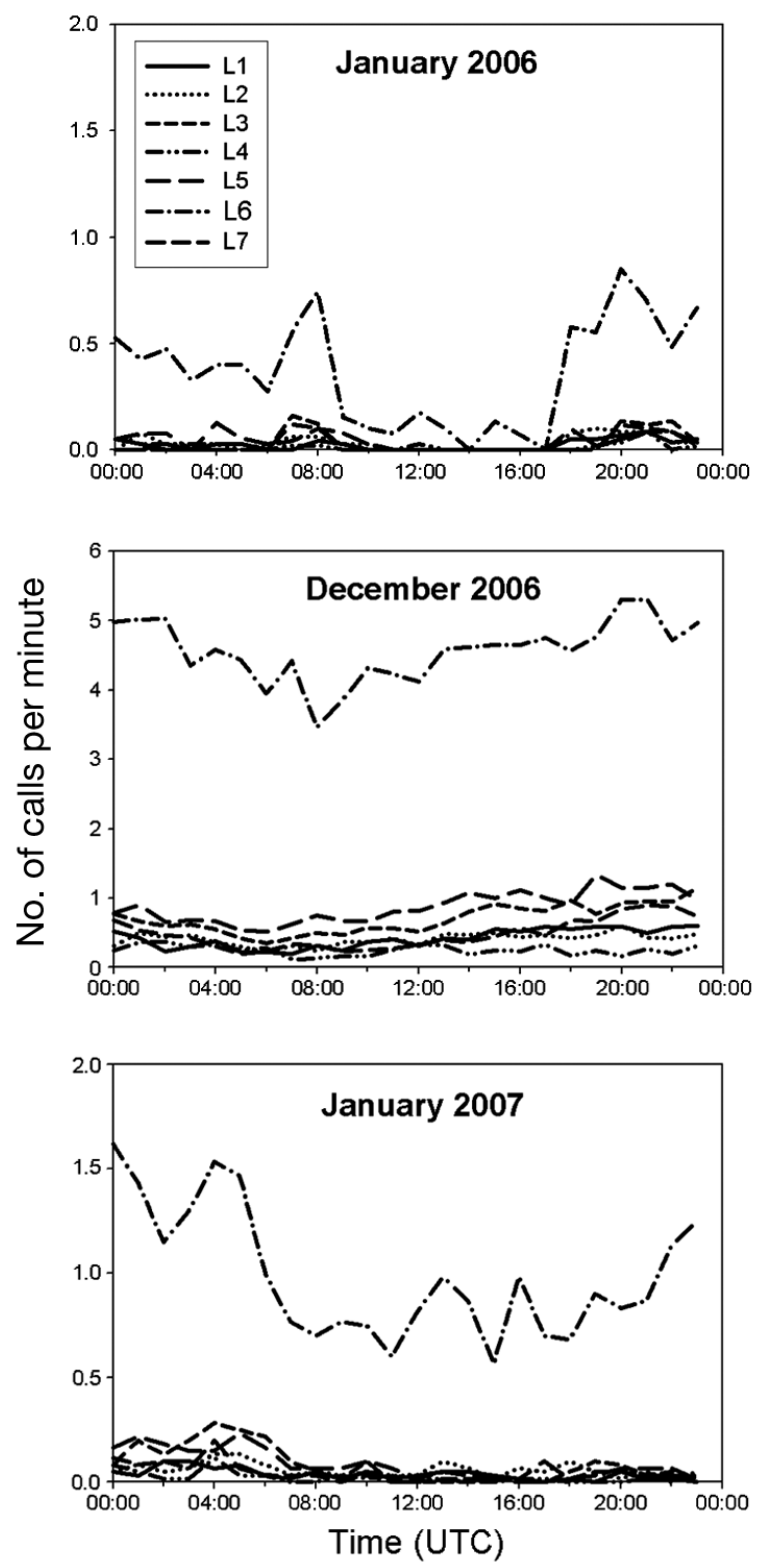

Fig. 11. Hydrurga leptonyx. Diel pattern of leopard seal call type usage (call types L1-L7) for months in which at least 100 leopard seal calls were recorded. Time is presented in Coordinated Universal Time (UTC); local time at PALAOA is UTC $-33 \mathrm{~min}$

vocal behavior. In addition, interactions with abiotic environmental factors, such as ice and the local soundscape, as well as biotic environmental factors, such as the distribution of prey and predators can also directly influence acoustic behavior. Interactions between abiotic factors and behavioral ecology (i.e. the influence of ice on mating strategy; Van Parijs et al. 2003) as well as between biotic factors and behavioral ecology (i.e. the effect of prey availability on distribution) can indirectly affect vocal behavior. Finally, anthropogenic factors such as climate driven changes
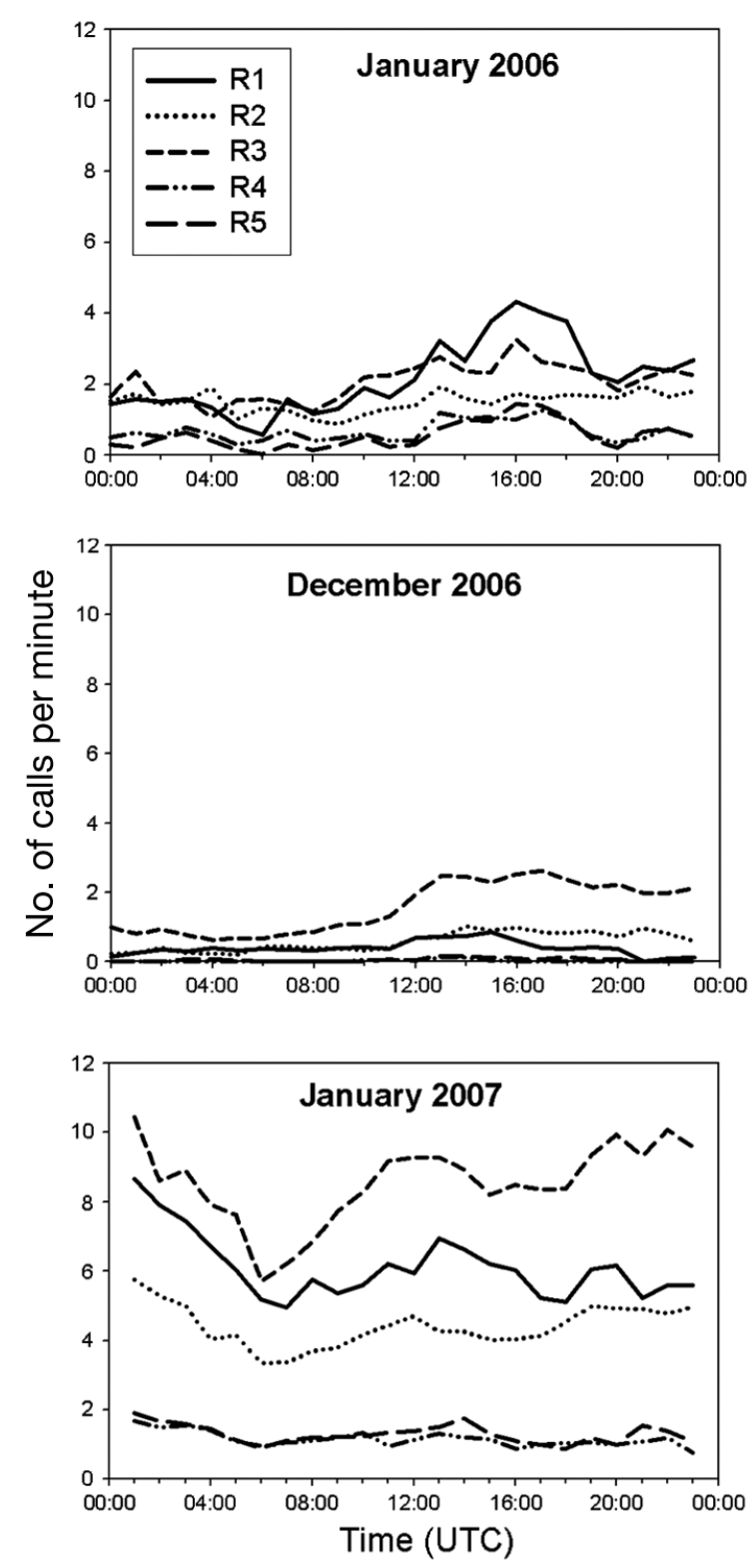

Fig. 12. Ommatophoca rossi. Diel pattern of Ross seal call type usage (call types R1-R5) for months in which at least 100 Ross seal calls were recorded. Time is presented in Coordinated Universal Time (UTC); local time at PALAOA is UTC - 33 min

and underwater noise can indirectly influence acoustic behavior, e.g. by affecting ice conditions and the local soundscape, respectively, and are therefore also a potentially important aspect of the acoustic ecology of Antarctic pinnipeds.

The results are discussed with respect to speciesspecific use of the acoustic environment based on the interactions shown in Fig. 16, recognizing that this is a non-exhaustive list while many of the factors mentioned are likely to act in concert and are of differing importance to each species. 

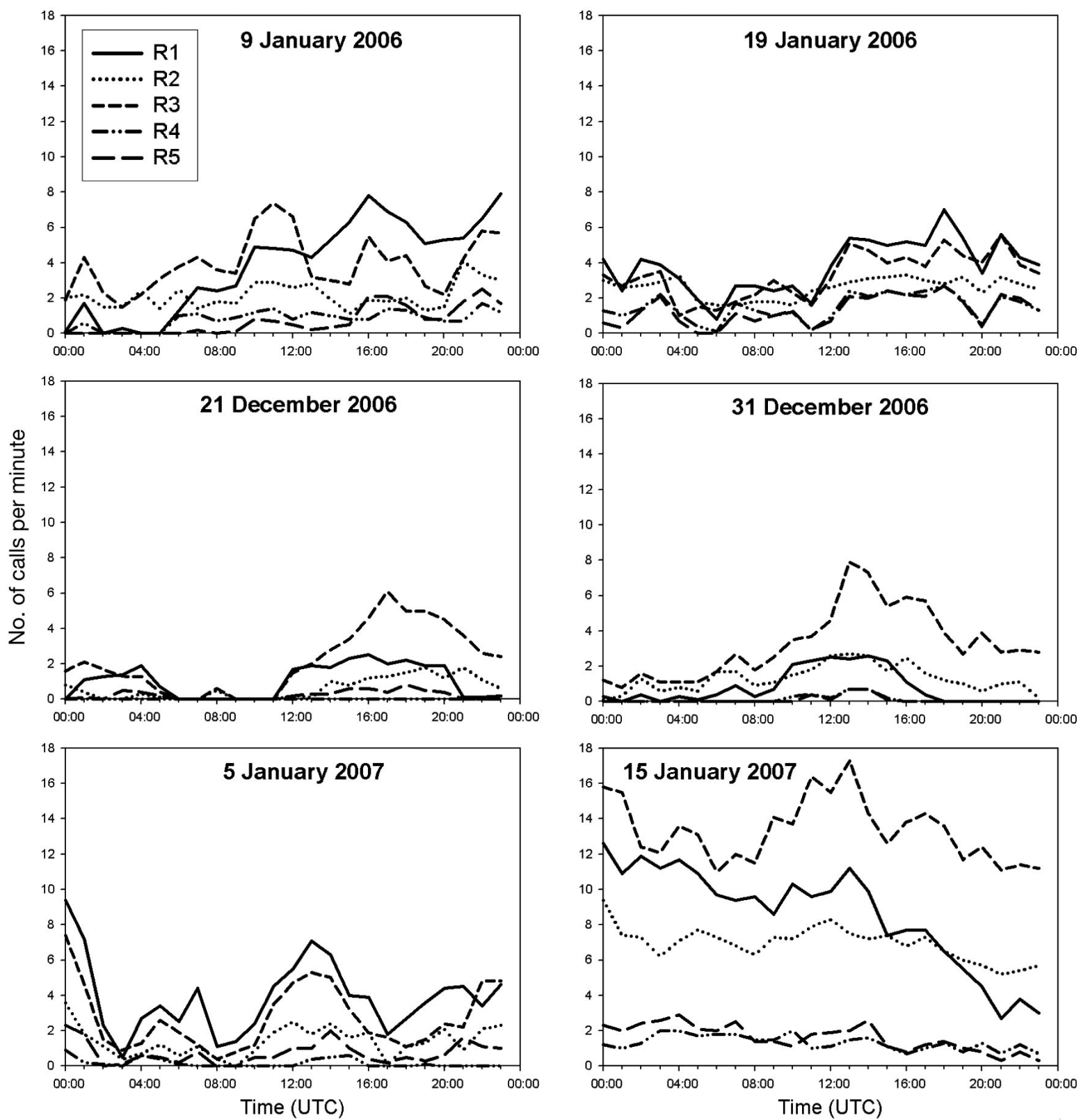

Fig. 13. Ommatophoca rossi. Diel pattern of Ross seal call activity on single days, chosen based on the variability in diel patterns, i.e. to illustrate the variation in vocal activity between days within the same month. Time is presented in Coordinated Universal Time (UTC); local time at PALAOA is UTC - $33 \mathrm{~min}$

\section{Behavioral ecology}

Mating system

Vocal repertoire size and acoustic presence. Vocal repertoire size is largely determined by the function of vocal behavior and the distance between the vocalizing individual and the targeted audience (Rogers 2003). The large size of the Weddell seal vocal repertoire, the relative complexity and the subtle variations between call types reflect that calls might be used in inter- and intrasexual communication over short distances and are therefore not constrained by signal propagation needs. Weddell seal vocalizations have been suggested to serve a function for males in maintaining underwater territories below the Antarctic fast-ice (e.g. Bartsch et al. 1992, Stirling \& Thomas 2003, Rouget et al. 2007). Nevertheless, as females move freely in this 3-dimensional underwater environment, males are unable to monopolize females and underwater territories might rather function as a display of male fitness for females and other males. This study showed that vocalizations 

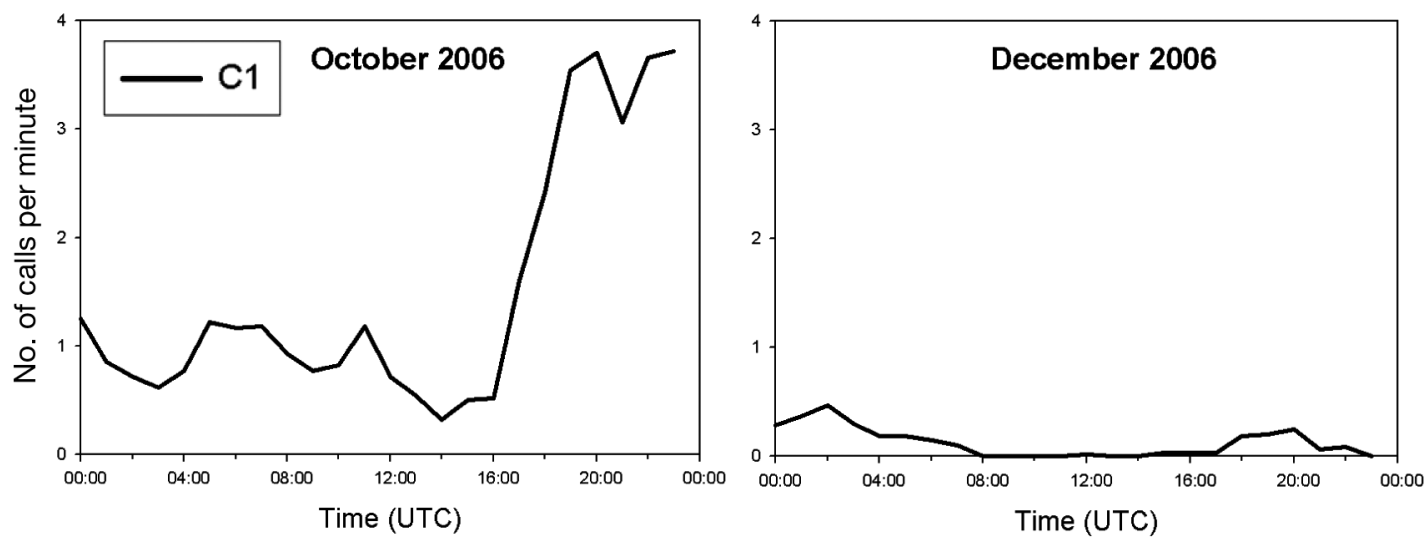

Fig. 14. Lobodon carcinophaga. Average diel pattern of crabeater seal call (type C1) usage for months in which at least $100 \mathrm{crab}-$ eater calls were recorded. Time is presented in Coordinated Universal Time (UTC); local time at PALAOA is UTC - 33 min

were recorded almost year-round, suggesting that a number of animals remain in the breeding area throughout the year. Males that occupy territories yearround might have an advantage over non-territorial males or males that move away in winter, in that they are already resident when females arrive at the breeding area (Harcourt et al. 2007, 2008). Their familiarity with the under-ice environment and neighbouring territorial males may reduce the cost of defending the breeding territory, which may eventually improve their mating success. The high Weddell seal vocal activity in winter and spring therefore suggests that males are actively engaged in acoustic displays in the breeding area for most of the year, and that the establishment and defense of underwater territories actually begins in winter, which is earlier than was previously assumed.

On the other hand, leopard and Ross seals are packice breeders that migrate to and beyond the outer
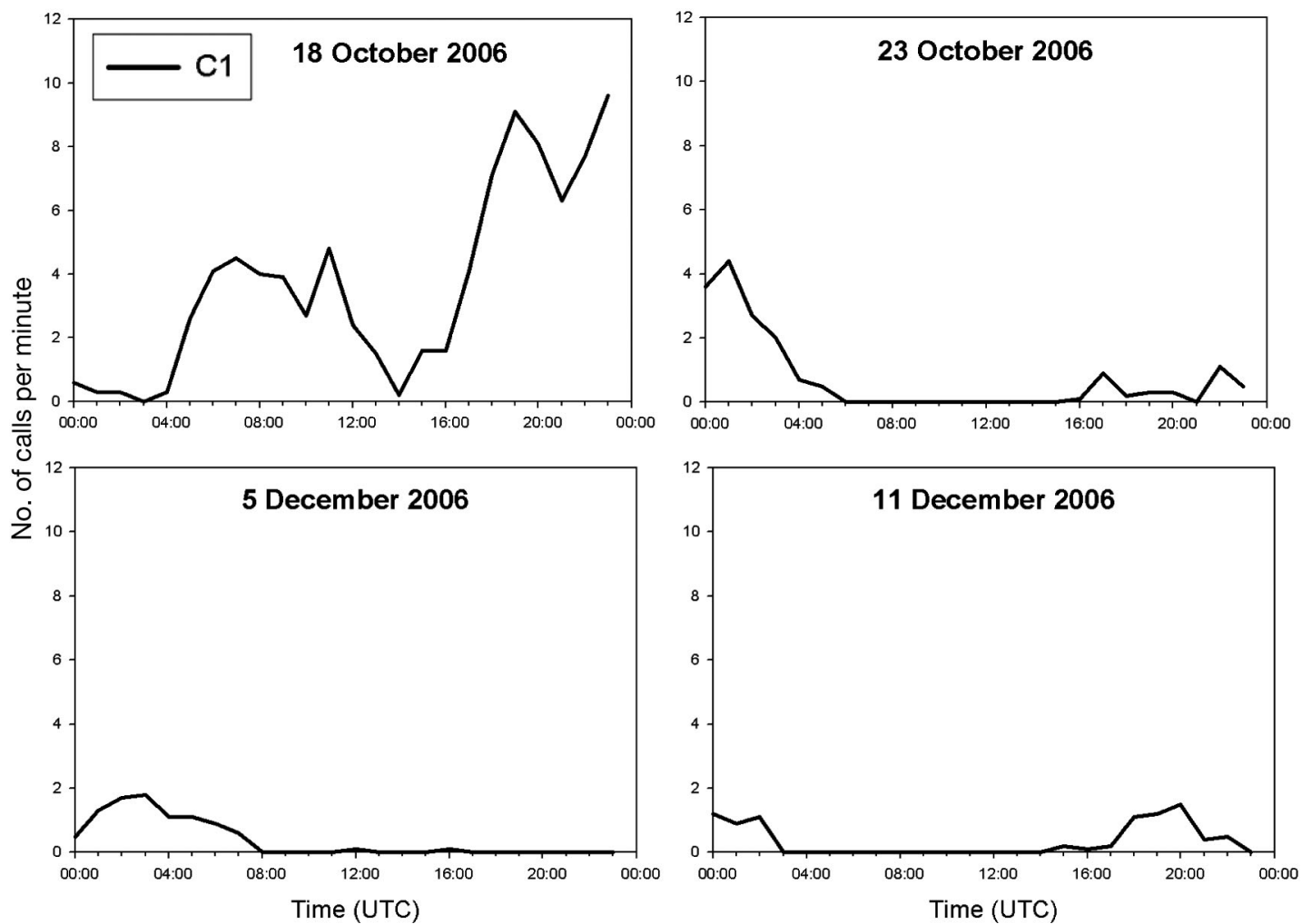

Fig. 15. Lobodon carcinophaga. Diel pattern of crabeater seal call activity on single days, chosen based on the variability in diel patterns, i.e. to illustrate the variation in vocal activity between days within the same month. Time is presented in Coordinated Universal Time (UTC); local time at PALAOA is UTC - $33 \mathrm{~min}$ 


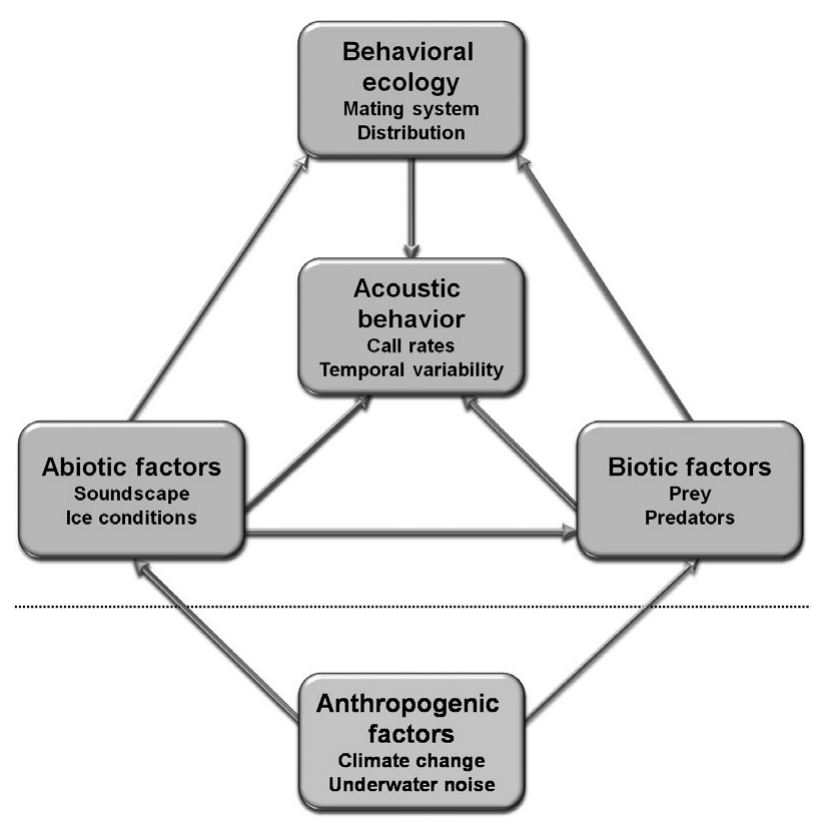

Fig. 16. Schematic representation of the acoustic ecology of Antarctic pinnipeds, showing how behavioral ecology, biotic factors and abiotic factors might interact to influence acoustic behavior of Antarctic pinnipeds

fringes of the Antarctic sea-ice in austral winter and move back into the inner pack-ice to breed in austral summer (Siniff \& Stone 1985, Blix \& Nordøy 2007). Females in these species are widely dispersed during the breeding season and calls are thought to function to attract mating partners over long distances. The medium-sized vocal repertoire of both species with highly stereotyped vocalizations may increase detectability of calls in spite of unfavorable propagation conditions and masking by background noise (Rogers 2003). In leopard seals, calls are produced by both sexes; females produce broadcast calls during the breeding season to signal their sexual receptivity, while leopard seal males call in search of mates (Rogers et al. 1995, 1996). Rogers \& Cato (2002) suggested that in leopard seals, information related to the individual may be encoded in the vocalization sequences, rather than in the acoustic characteristics of call types, given that sequences may be less affected by signal degradation when communicating over long distances. In addition, the narrow frequency bandwidth of leopard seal calls and their long calling periods may also increase the chance that receivers recognize calls under poor signal-to-noise ratios.

For Ross seals, very little is known on mating behavior. Mating has been suggested to occur in December (King 1969) or around October-November immediately following pupping at the outer edge of the packice zone (Thomas et al. 1980, Bengtson \& Stewart 1997 , Blix \& Nordøy 2007). Based on the seasonal peak in
Ross seal acoustic activity, we suggest that Ross seal mating in the Atka Bay region takes place relatively near the ice shelf region between December and January. Studies on several other aquatic mating pinnipeds have shown that seasonal peaks in vocal activity coincide with the period in which mating occurs (harbour seal: Van Parijs et al. 1999; leopard seal: Rogers et al. 1996; hooded seal: Ballard \& Kovacs 1995; bearded seal: Van Parijs et al. 2001; grey seal: Asselin et al. 1993). Assuming that Ross seal mating occurs primarily in January, when the peak in vocal activity occurs, this also sheds new light on previous observations of changes in male Ross seal dive patterns in January (Southwell 2005, Blix \& Nordøy 2007). Southwell (2005) noted that the male Ross seal dive pattern changed from longer presumably foraging dives in December to predominantly short dives with a modal duration of 1 to 2 min in January. These male Ross seal dive patterns in January are reminiscent of descriptions of typical male dive display behavior of other phocid species during the mating season (Van Parijs et al. 1997, 2003).

Crabeater seals only produce the moan $(\mathrm{C} 1$, comprising both the high and low moan variety; Klinck et al. 2010) in the PALAOA recordings. Crabeater seals breed on pack-ice and are serially monogamous (Siniff et al. 1979). The relatively simple acoustic display of crabeater seals consisting of short broadband calls is thought to function primarily in short-range underwater male-male competition (Shaughnessy \& Kerry 1989, Rogers 2003). Crabeater seal males, in contrast to Weddell, leopard and Ross seal males, are able to monopolize females and haul out on ice floes to guard a female with her pup against intruder males until the pup is weaned and the female enters estrus. Once the pup is weaned and the female leaves the ice, the male is assumed to mate with the female. Rogers (2003) hypothesized that in crabeater seals a loud welldeveloped vocal display would likely attract males to the female that the male is defending, whereas the acoustic characteristics of the moan limit the signal to be received only by rival males in the vicinity. A recent study identified 4 additional crabeater seal call types which were recorded from a single animal of unknown sex and age in February 2007 (McCreery \& Thomas 2009). The acoustic characteristics of these newly described crabeater seal call types and the month in which they were recorded, suggest that these calls serve as short-range communication and are not necessarily produced in a breeding context, comparable to the short-range call types that have been recorded from captive leopard seals (Rogers et al. 1996). The short-range call types described by McCreery \& Thomas (2009) were not present in the PALAOA recordings analysed in this study. This suggests that 
the distance between the calling animals and PALAOA might simply have been too large to record these call types, rather than that these call types were absent from the vocal repertoire of the animals in the Atka Bay region.

Repertoire composition. In aquatic mating pinnipeds, competition between males is likely to become more intense towards the period that females enter estrus (see Van Parijs 2003 for examples). The intensification of male agonistic encounters could be reflected by the usage of specific call types. Some of the Weddell seal call types (e.g. W1, W9, W10, W13, W6) have in previous studies been described as territorial or threat calls functioning in male-male and male-female interactions during the breeding season (e.g. Watkins \& Schevill 1968, Thomas et al. 1983, 1988). The highest monthly proportional usage of such proposed threat call types in this study occurred in June and December (W13 and W6 respectively) whereas call types W1 and W10 had a relatively constant proportional usage throughout the year. As Weddell seal vocalizations are thought to serve a function in maintaining underwater territories throughout the year (e.g. Bartsch et al. 1992, Rouget et al. 2007), this might explain why threat calls form such a consistent portion of the vocal repertoire during winter. Alternatively or in addition, these threat calls may also be produced in the context of gaining access to breathing holes in winter. During austral winter the number of open tidal cracks and leads in the fast ice is limited, with the presence of cracks being the major determinant of Weddell seal distribution in austral winter (Lake et al. 2005). This may result in competition between Weddell seals of both sexes for access to breathing holes. Several studies have observed both male and female Weddell seals to vocalize upon ascent to breathing holes, possibly to chase away other individuals from the hole (Watkins \& Schevill 1968, Evans et al. 2004, Terhune \& Dell'Apa 2006).

Weddell seal call type W8 was used only between May and December and showed a peak in proportional usage from August to October, the early onset of the breeding season. This call type has been described as the 'guttural glug' by Thomas et al. (1983) and Pahl et al. (1997) and is assumed to have a threat function. Most of the females are hauled out on the ice for extended periods in October to give birth and suckle their pups (e.g. Tedman \& Bryden 1979 Thomas \& DeMaster 1982, Reijnders et al. 1990) and call type W8 might therefore be used mainly or specifically by males, serving a function in male-male competition. The proportional usage of these calls decreases towards the peak mating period in November-December, possibly reflecting that calls used for mate attraction become more prominent in this period. Alternatively, males might also use fewer territorial calls in this period because males are settled in their territories. Injured males are often seen hauled out on the ice alongside whelping females (I. Van Opzeeland pers. obs.), possibly reflecting that contests for underwater territories might have subsided in this period. Call type W14 predominated during the mating (Ma) and mating+lactation (LM) period. This call type has been repeatedly observed to be produced in-air by female Weddell seals on the ice (I. Van Opzeeland pers. obs.) and possibly represents a call type that is produced mainly or exclusively by females. Given the period that these calls were most predominant, they could serve to signal female receptivity to males.

In contrast to Weddell seals, the vocal repertoire composition of the pack-ice breeding species remains relatively similar throughout their calling period, reflecting that the function of these vocalizations is potentially relatively uniform throughout the breeding season and that there are no stages within the mating season causing gradual change in repertoire composition as observed in Weddell seals.

For the pack-ice breeding species, their distance from the observatory might cause some calls to be too faint to be recorded, whereas such a bias is unlikely for Weddell seals which are located on the fast-ice within Atka Bay and just north of PALAOA. The precise location from which the pack-ice breeding seals vocalize is not known, but in austral summer the nearest pack-ice areas are located within 10 to $20 \mathrm{~km}$ off the fast-ice edge where PALAOA is located. In both the leopard and Ross seal vocal repertoire, low frequency calls L6 and R3 were the most predominant call types. These lower frequency calls are likely to transmit over longer distances than the other call types, increasing the chances of detecting these calls compared to other call types. Alternatively, the high proportion of these lower frequency call types in the vocal repertoire might be real, reflecting precisely that these calls are used most often because of their larger detection ranges. The vocal repertoire of captive leopard seals was dominated by call types L3, L4 and L6 supporting our observation that L6 forms one of the predominant call types of the leopard seal vocal repertoire (Rogers et al. 1996).

For crabeater seals, separate analysis of both varieties of moan showed that the low moan vocalization occurred from August to December, wheareas high moans occurred primarily in the first half of November (Klinck et al. 2010), which is the period in which most females enter estrus (e.g. Siniff et al. 1979, Shaughnessy \& Kerry 1989). It is not known if female crabeater seals also produce underwater vocalizations and if the occurrence of the high moan could possibly be attributed to females advertising their sexual receptivity. Alternatively, the occurrence of the high moan in the first half of November might also link this 
call type to male crabeater seals in periods when intra-sexual competition for access to estrus females is strongest.

Diel call activity patterns. Weddell seal diel call activity patterns differed substantially between months and were in accordance with the patterns in call activity described by Rouget et al. (2007) who monitored Weddell seal underwater vocal activity from July to November. The low vocal activity during winter daytime hours is unlikely to be explained by haul-out behavior, as seals are rarely observed on the ice in this period (e.g. Sato et al. 2003, Rouget et al. 2007). Weddell seals are known to depend on visual cues for underwater orientation, hunting and location of breathing holes (Kooyman 1975, Wartzok et al. 1992, Burns et al. 1999, Davis et al. 1999). This led Rouget et al. (2007) to suggest that the daytime periods with low vocal activity in July-August could potentially be explained by the limited number of light hours in that period which seals might utilize for vision-dependent activities during which they vocalize less. However, we also observed this bimodal pattern in vocal activity in May and June when global radiation is low and the light-dark cycle is virtually absent at the site where this study was conducted (Koenig-Langlo \& Herber 1996). This suggests that Weddell seals use an alternative cue to entrain their circadian rhythm in the period of constant darkness in winter. Bornemann et al. (1998) found a correlation between tidal rhythmicity and semi-circadian rhythm of Weddell seal underwater activity in summer; they suggested that in summer tidal movement might affect abundance and distribution of prey and that Weddell seals use the tide as a time cue to optimize foraging efficiency. However, Testa (1994) showed that Weddell seal dive depths in midwinter darkness lacked the diel pattern of autumn and spring dives. This leaves it unlikely that low vocal activity during winter daytime hours could be explained by Weddell seal foraging activity during which they would vocalize less or in deeper waters beyond recording range (e.g. Rouget et al. 2007). Alternatively, the observed diel rhythm in Weddell seal vocal activity might be entrained by social factors. Animals across various taxa inhabiting environments that lack time cues are known to socially and mutually synchronize circadian rhythms (e.g. Crowley \& Bovet 1980, Marimuthu et al. 1981, Aschoff et al. 1983). Similarly, Weddell seals might use the vocalizations of conspecifics to synchronize their own vocal activity. In addition, all 6 call types that occurred frequently enough to be included in the diel pattern analyses have been described previously and are thought to have a territorial and/or threat function (Watkins \& Schevill 1968, Thomas et al. 1983). Social synchronization of vocal activity might aid to maximize the effectiveness of signals used in male-male competition and female attraction. Towards September the diel rhythm becomes less pronounced, which might be explained by the fact that male-male competition becomes more intense and vocal interactions occur more continuously. Adult males, territorial males in particular, are known to rarely haul out from early October through mid December and spend most of the breeding season under the fast ice (Harcourt et al. 2007).

Similar to Weddell seals, leopard and Ross seals both exhibited continuous call activity in the months in which mating takes place which might on the one hand reflect the absence of factors constraining or influencing vocal activity and on the other hand the increased competition for mating partners promoting continuous vocal activity. These findings are in accordance with previous studies that found that most Ross seals haul out around solar midday in December, while haul-out patterns in January were more variable (Southwell et al. 2003, 2008).

For leopard seals, the continuous call activity observed in December could possibly be explained by a difference in male and female call strategies. Rogers et al. (1995) observed leopard seals in captivity and noted that the female called constantly for many days when she was sexually receptive, whereas males called throughout December and January. For males it might be more advantageous to advertise their presence over longer periods during the breeding season, which might introduce a trade-off between the hourly call rate and the total period over which a male can energetically afford to be vocally active. Males might therefore vocalize mainly during the hours that most females are in the water, whereas females might vocalize more continuously throughout the short period in December that they are in estrus. Given that previous studies found a clear diel pattern in leopard seal vocal activity in December (Thomas \& DeMaster 1982, Rogers \& Bryden 1997), a possible explanation for the observed difference might be the ratio of male and female callers at the different recording locations.

In addition, local ecological factors might also affect vocal behavior differently between recording locations. Van Parijs et al. (1999) found that harbour seal males adapted their temporal and spatial behavior to the periods when most females were in the water. Sitespecific differences in ecological constraints on haulout behavior of female harbour seals were therefore reflected in local variation in male display behavior. The absence of environmental factors such as prey availability constraining or influencing vocal activity at Atka Bay might therefore result in the continuous leopard seal vocal activity in December, whereas environmental factors might affect the vocal activity patterns in other areas differently.

In crabeater seals, the intensification of malemale competition might have a contrary effect on call 
activity compared to the other species. Competition between males for access to receptive females might force males to remain hauled out for extended periods during the day to defend the female against intruders. In November, periods of vocal activity might therefore be more restricted to the night and early morning hours, which is in accordance with the pattern in vocal activity observed in other studies (Thomas \& DeMaster 1982, Klinck et al. 2010). The difference in call activity pattern in October and December might reflect that crabeater seal vocal behavior develops into a typical 2-peak pattern from start to peak mating season, resulting from such intensification in male-male competition.

\section{Distribution}

In contrast to leopard, Ross and crabeater seals, Weddell seals are relatively stationary, remaining in fast-ice areas where the presence of cracks and breathing holes determine their distribution (e.g. Stirling 1969, Lake et al. 2005). The species' sedentary nature is likely to explain the existence of geographical variation in vocal behavior on various spatial scales (Abgrall et al. 2003, Thomas \& Stirling 1983). Trills and calls thought to have a function in territorial defense such as call type W6, were present at all sites, while all sites also had unique call types that were not shared with other breeding populations. This study identified 14 Weddell seal call types, 13 of which have been described previously. Nevertheless, the differences between call type representation, description and classification methods provided in a number of previous studies complicate the comparison of call types between study sites. In most cases call types recorded in this study exhibited subtle differences in acoustic structure compared to the call types recorded at other breeding populations, such as e.g. the different types of descending chirp sequences that have been described (Terhune et al. 1994, Moors \& Terhune 2004, Hayes \& Terhune 2007). However, none of these descriptions included the presence of a short ascending whistle, which in this study always preceded call type W2 and in some cases also W3, albeit in a less stereotyped form. Pahl et al. (1997) described this ascending whistle as a separate call type (call type DC202). Despite these differences, overall similarity in call characteristics and structure showed that all call types, with the exception of W4, could be classified into previously described call types. Call type W4 (Fig. S1) represents a strongly stereotyped chirp sequence that differed from the chirp sequences recorded at other sites. In contrast to the similar looking call types W2 and W3, call type W4 consists of 3 falling chirp seg- ments followed by a low chirp. Call type W4 might therefore represent a site- or region-specific call for Atka Bay that is not used in other Weddell seal populations.

Leopard, Ross and crabeater seals move over much larger spatial scales, which might also be reflected in the absence of large differences in vocal repertoire composition. In accordance to our findings, previous studies report leopard seal call types L6 ('low double trill') and L3 ('high double trill') to be the most common call types (e.g. Stirling \& Siniff 1979, Rogers \& Cato 2002). However, call repertoire composition varies between different locations (e.g. Thomas \& Golladay 1995, Rogers 2007). Most of the call types in the PALAOA recordings have also been recorded at Prydz Bay, except for call type L4 ('hoot'), which has only been recorded in captivity (Rogers et al. 1996). Rogers (2007) noted that call type L5 ('hoot with single trill') was only recorded at 2 opposing locations of the Antarctic continent, Prydz Bay and the South Shetland Islands, and not at any of the sites in between. However, we found call type L5 also to be present in the PALAOA recordings, which may suggest that there is movement of animals between the South Shetlands, Prydz Bay and Atka Bay. Differences between local vocal repertoires can be used to make inferences about potential movement and exchange patterns between populations (e.g. Perry \& Terhune 1999, Cerchio et al. 2001). In leopard seals, this is particularly exciting as genetic studies have shown that there is sufficient gene flow between breeding groups to prevent development of population structure (Davis et al. 2008). Nevertheless, it has been suggested that the fact that there is geographic variation in vocal repertoiresdespite the low genetic variability between animals from different regions - could indicate that some animals show site fidelity and that moving (potentially juvenile) leopard seals adapt their vocal repertoire to that of local breeding groups (Davis et al. 2008).

In our analyses, we did not discriminate between the 'mid double trill' and 'mid single trill' (Stirling \& Siniff 1979, Rogers et al. 1996) and lumped all mid trills into call type L7 (Fig. S2). However, Klinck (2008) found that both mid trill types were present in the leopard seal vocal repertoire recorded at Atka Bay. The 'mid double trill' has so far only been recorded from animals in the South Shetlands (Rogers 2007), which could be an indication that there is movement of animals between the South Shetlands and Atka Bay, but not directly between Prydz Bay and the South Shetlands. However, further investigation is needed to gain insights into the relationship between leopard seal local vocal repertoires and movement patterns.

For Ross seals, 4 of 5 call types in the PALAOA recordings have been described previously (Watkins \& 
Ray 1985, Stacey 2006) while one was only present in the PALAOA recordings (Seibert 2007). Although Watkins \& Ray (1985) and Stacey (2006) used different methods to categorize call types, their descriptions confirm that at least R1, R2 and R3 have also been recorded at other locations. Stacey (2006) also distinguishes a call type that looks similar to call type R5 in this study ('underwater call type B'). We found call type R5 to be almost always associated with R4, which is also reflected in the similar proportional usage of these call types within the repertoire. However, both call types also occurred independently, which is why we have assigned separate call type names. The absence of call type R4 in previous descriptions of the Ross seal repertoire could indicate that $\mathrm{R} 4$ is a regionspecific call and that Ross seal call repertoires differ between areas.

\section{Biotic factors}

Prey availability

In many species, past experience with spatially and temporally predictable food sources might cause animals to return to and concentrate in these areas during periods that resources are abundant (Krebs \& Davies 1993). The timing of the leopard seal mating period, following the weaning of pups after which both females and pups require extra food resources, might have evolved to coincide with the period when the sea ice breaks back towards the colonies and penguin fledglings and seal weanlings are compelled to leave the ice (Klinck 2008). Most leopard seal calls were recorded in December which coincides with the period in which mating occurs. In this period the presence of the emperor penguin Aptenodytes forsteri colony as well as the crabeater and Weddell seal breeding colonies in and around Atka Bay likely provide an attractive feeding spot for leopard seals. Given that leopard seals are solitary animals outside the breeding season, the presence of food sources that are reliably present in Atka Bay every year might also function to attract leopard seals to the breeding area and increase the likelihood of finding a mating partner. In addition to their own calls, the sounds from the penguin and seal colonies might also function as 'acoustic beacons' where many animals concentrate to mate and forage.

\section{Presence of predators}

For crabeater seals, the likelihood of encountering predators might be a factor influencing the timing of vocal activity. Vocalizing crabeater seals might provide location cues to leopard seals and might consequently increase their predation risk. Gilbert \& Erickson (1977) suggested that crabeater seals might represent a more important leopard seal food source than krill or penguins. The peak in crabeater vocal activity in our data set occurred in October. The peak in crabeater call activity in November occurred when only few leopard seal calls were present in the recordings, suggesting that leopard seals might not yet be abundantly present at Atka Bay in this period. However, most crabeater seal body wounding by leopard seals has been suggested to occur between weaning and attaining maturity (Siniff \& Bengtson 1977). If this reflects the main age class that is targeted by leopard seals, the majority of leopard seals might time their arrival in late November/ early December to coincide with the period when most crabeater seal pups are weaned.

The presence of leopard seals, in turn, might be restricted to the period that orcas Orcinus orca are absent. Although the extent remains unknown, Siniff \& Bengtson (1977) found evidence for leopard seal predation by orcas. Preliminary analysis of the PALAOA data show that in subsequent years, orca echolocation clicks and vocalizations are present in the January recordings when leopard seal vocal activity decreases rapidly. However, further analyses of annual patterns in cetacean vocal behavior are underway and will provide further insight into such inter-specific relationships.

\section{Abiotic factors}

Soundscape: inter-specific acoustic niche partitioning

The observed differences between species in timing of acoustic behavior might reduce acoustic interference between calling individuals (i.e. jamming of signals) and increase the efficiency of signal propagation (e.g. Sueur 2002). Partitioning of the acoustic environment or sequencing of acoustic activity, either based on time, space or frequency bandwidth of signals, is referred to as acoustic niche forming (Latimer \& Broughton 1984, Mossbridge \& Thomas 1999, Sueur 2002, Brumm 2006, Boquimpani-Freitas et al. 2007) and has been observed to occur both intra-specifically and inter-specifically in orthopterans, amphibians and birds (e.g. Ficken \& Hailma 1974, Gerhardt 1994). Harp seals are thought to overcome masking by calls of conspecifics by using frequency and temporal separation of call types (Serrano \& Terhune 2002). Mossbridge \& Thomas (1999) suggested that orcas modulate the frequency of their vocalizations as an adaptation to the presence of leopard seals during periods that both species exploit the same region. Particularly for species that rely on signal propagation over long distances 
to find a mating partner, such as leopard and Ross seals, acoustic niche forming might significantly reduce interspecific acoustic interference. Leopard and Ross seal calls dominate the soundscape during relatively short distinct periods in December and January respectively and might temporarily 'block' the acoustic space of other species. Such 'blocking' of acoustic space might occur through the relatively high amplitude of leopard seal calls (Rogers 2003) as well as the broad frequency bandwidth that is covered by Ross seal vocalizations, and might contribute to prevent inter-specific acoustic interference. Weddell and crabeater seals on the other hand, communicate over much shorter distances and might therefore not depend so much on efficient signal propagation. Complete separation of the period during which a species is vocally active might on the other hand not be possible because of other abiotic and biotic factors, such as the availability of prey, suitable ice and thermoregulation (haul out) which might further restrict the breadth of the acoustic niche of each species.

Ice conditions

The observed differences in the number of calls in January 2006 and January 2007 for Weddell, leopard and Ross seals suggests that a lower number of animals was present in the area around the observatory in 2006 compared to 2007. Despite the difference in the number of samples that were analysed in January 2006 and 2007, in both years samples were not biased towards certain times of day during which vocal activity was higher and such a sampling bias cannot therefore have influenced the results. Although Weddell, leopard and Ross seals depend on different ice types for breeding, they all rely on the large-scale reliability of sea-ice development. Previous studies found that inter-annual variability in sea-ice extent and composition affects behavior of ice-breeding pinnipeds: Siniff et al. (2008) observed fewer adult Weddell seals at the breeding area in McMurdo Sound in a year when ice closed off cracks that had reliably been open in previous years. In bearded seals, the number of displaying males was found to be restricted by between-year fluctuations in ice cover (Van Parijs et al. 2004). Not only differences in ice conditions between years might affect pinniped acoustic behavior, but seasonal availability of ice suitable for haul-out and pupping might also affect vocal behavior. The absence of Weddell seal vocalizations in the PALAOA recordings throughout February might reflect a short period during which seals might have moved (either actively or drifting passively on ice floes) out of Atka Bay to areas where suitable ice for haul-out was still present. Weddell seals aggregate along pre- dictable annual tidal cracks in the fast ice close to the ice shelf edge of Atka Bay (J. Plötz pers. obs.). Seasonal fast-ice breakup in this area usually occurs in February, after which the ice sheet builds up again in March and April (G. König-Langlo pers. comm). Green \& Burton (1988) also observed a very low number of Weddell seal calls in Long Fjord near Davis station $\left(68^{\circ} \mathrm{S}, 78^{\circ} \mathrm{E}\right)$ between February and early April, followed by a period with a distinct lack of Weddell seal vocal activity in May and June during which no seals were sighted in the area. They suggested that the limited amount of ice available for seals to haul out on in addition to the potentially depleted food stocks in the pupping area might have caused seals to move out of the fjord. Alternatively, if calls play a role in Weddell seal territorial disputes throughout the year, as discussed previously, vocal activity might be linked exclusively to the presence of fast-ice being a prerequisite for the existence of underwater territories. In this case, seasonal fast-ice break-up in February would dissolve the underwater territorial system which might be reflected in the absence of Weddell seal vocalizations in this month.

\section{Implications of a changing environment for Antarctic pinnipeds}

All 4 species rely on different sea-ice habitats for most or at least critical portions of their life history and the effects of climate change are therefore likely to have differing impacts on each species. In Weddell seals, population dynamics have been linked to climatological cycles, mediated through changes in sea-ice extent and concentration (Testa et al. 1991, Siniff et al. 2008). Pup incidence was lower in years when sea-ice was more extensive, possibly related to decreased foraging success through the reduced amount of open water available for primary production ultimately affecting fish availability (Hadley et al. 2007). In crabeater seals, ice extent might also have an indirect impact given that sea-ice extent affects recruitment and abundance of krill, their primary prey (Siniff et al. 2008). Moreover, for pupping, crabeater seal females select ice floes based on floe size and physical characteristics (i.e. surface relief; Siniff et al. 1979) which offer protection from predation by leopard seals and orcas. Changes affecting the availability and duration of availability of such sea-ice types might also directly affect crabeater seal populations, e.g. through reduced reproductive success when floes melt before lactation is complete. Siniff et al. (2008) suggested that leopard and Ross seals might be less sensitive to changes in sea-ice given the fact that they are not philopatric with respect to breeding areas. However, this study and 
preliminary analyses of PALAOA data from following years show that calls of leopard and Ross seals reoccur each year and coincide with the mating period. Although information from Atka Bay on site-fidelity at an individual level is lacking, the PALAOA data suggest that at least on a species level animals return to the same breeding areas each year and might therefore be more philopatric than previously thought. Consequently, for these species local changes in ice conditions might also result in loss of site-specific breeding locations. Such changes might in turn also have consequences for other species, for example through shifts in timing of mating and the resulting changes in acoustic space. Acoustic techniques form an important tool to monitor such reponses to human-induced changes in environmental conditions (Laiolo 2010), particularly in remote areas such as the Antarctic.

Compared to other areas in the world, the Antarctic is still a relatively pristine area with respect to anthropogenic impact (Halpern et al. 2008). However, as in many other marine ecosystems, anthropogenic impact such as noise caused by e.g. vessels or seismic exploration can influence marine mammals in various ways (see Southall et al. 2007 for a review). Changes in the local soundscape as a result of anthropogenic activities can alter vocal behavior of species in affected areas or affect prey distribution (Southall et al. 2007) and are therefore also of potential influence on the acoustic ecology of Antarctic pinnipeds. To understand these impacts, knowledge on how species use acoustic space and the factors that shape acoustic behavior is indispensable.

Further investigation involves multi-year comparisons of vocal behavior of Antarctic pinnipeds and integration of the acoustic data in habitat models to contrast environmental attributes associated with seasonal occurrence and call rates. These approaches will contribute to improve our understanding of the fundamental ecology and acoustic ecology of Antarctic pinnipeds.

Acknowledgements. S. Riedel, D. Steinhage, A. Ziffer and the overwintering teams 2005 and 2006 (Alfred Wegener Institute for Polar and Marine Research, Bremerhaven, Germany), H. Schubert (Reederei F. Laeisz GmbH, Rostock, Germany), R. Verhoeven, J. Hoffmann and C. Müller (FIELAX Services for Marine Science and Technology $\mathrm{mbH}$, Bremerhaven, Germany) all played crucial roles in setting up and/or maintaining PALAOA. The PALAOA project was partly funded by the Bremerhavener Gesellschaft für Innovationsförderung und Stadtentwicklung (BIS). We thank 4 anonymous referees for their constructive comments on our manuscript.

\section{LITERATURE CITED}

Abgrall P, Terhune JM, Burton H (2003) Variation of Weddell seal (Leptonychotes weddellii) underwater vocalizations over mesogeographic ranges. Aquat Mamm 29:268-277
Aschoff J, Von Goetz C, Honma KI (1983) Restricted feeding in rats: effects of varying feeding cycles. Z Tierpsychol 63: 91-111

> Asselin S, Hammill MO, Barrette C (1993) Underwater vocalizations of ice-breeding grey seals. Can J Zool 71: 2211-2219

Ballard KA, Kovacs KM (1995) The acoustic repertoire of hooded seals (Cystophora cristata). Can J Zool 73: 1362-1374

Bartholomew GA (1970) A model for the evolution of pinniped polygyny. Evolution 24:546-559

Bartsch SS, Johnston SD, Siniff DB (1992) Territorial behavior and breeding frequency of male Weddell seals (Leptonychotes weddellii) in relation to age, size and concentrations of serum testosterone and cortisol. Can J Zool 70: $680-692$

Bengtson JL (2002) Crabeater seal (Lobodon carcinophaga) In: Perrin WF, Wursig B, Thewissen JGM (eds) Encyclopedia of marine mammals. Academic Press, San Diego, CA, p 302-304

Bengtson JL, Stewart BS (1997) Diving patterns of a Ross seal (Ommatophoca rossii) near the eastern coast of the Antarctic Peninsula. Polar Biol 18:214-218

Bester MN, Odendaal PN (2000) Abundance and distribution of Antarctic pack-ice seals in the Weddell Sea. In: Davison W, Howard-Williams C (eds) Antarctic ecosystems: models for wider ecological understanding. Caxton Press, Christchurch, p 59-63

Blix AS, Nordøy ES (2007) Ross seal (Ommatophoca rossii) annual distribution, diving behaviour, breeding and moulting, off Queen Maud Land, Antarctica. Polar Biol 30: 1449-1458

Boebel O, Kindermann L, Klinck H, Bornemann H and others (2006) Real-time underwater sounds from the Southern Ocean. Eos Trans AGU 87:361-362

Boquimpani-Freitas L, Marra RV, Van Sluys M, Rocha CFD (2007) Temporal niche of acoustic activity in anurans: interspecific and seasonal variation in a neotropical assemblage from south-eastern Brazil. Amphib-reptil 28: $269-276$

> Bornemann H, Mohr E, Plötz J, Krause G (1998) The tide as a zeitgeber for Weddell seals. Polar Biol 20:396-403

Brumm H (2006) Signalling through acoustic windows: nightingales avoid interspecific competition by short-term adjustment of song timing. J Comp Physiol A 192: 1279-1285

Burns JM, Castellini MA, Testa JW (1999) Movements and diving behavior of weaned Weddell seal (Leptonychotes weddellii) pups. Polar Biol 21:23-36

Catchpole CK, Slater PJB (2008) Bird song: biological themes and variations, 2nd edn. Cambridge University Press, Cambridge

Cerchio S, Jacobsen JK, Norris TF (2001) Temporal and geographical variation in songs of humpback whales, Megaptera novaeangliae: synchronous change in Hawaiian and Mexican breeding assemblages. Anim Behav 62: 313-329

Cleator H, Stirling I, Smith TG (1989) Underwater vocalizations of the bearded seal (Erignathus barbatus). Can J Zool 67:1900-1910

Cotté C, Guinet C (2007) Historical whaling records reveal major regional retreat of Antarctic sea ice. Deep-Sea Res I 54:243-252

- Crowley M, Bovet J (1980) Social synchronization of circadian rhythms in deer mice (Peromyscus maniculatus). Behav Ecol Sociobiol 7:99-105

> Davis RW, Fuiman LA, Williams TM, Collier SO and others 
(1999) Hunting behavior of a marine mammal beneath the Antarctic fast ice. Science 283:993-996

Davis CS, Stirling I, Strobeck C, Coltmann DW (2008) Population structure of ice-breeding seals. Mol Ecol 17: 3078-3094

Emerson SB (1992) Courtship and nest-building behavior of a Bornean frog, Rana blythi. Copeia 1992:1123-1127

Erickson AW, Hanson MB, Kehoe DM (1983) Population densities of seals and whales observed during the 1983 circumnavigation of Antarctica by the USCGC Polar Star. Antarct J US 18:163-166

Evans WE, Thomas JA, Davis RW (2004) Vocalizations from Weddell seals (Leptonychotes weddellii) during diving and foraging. In: Thomas J, Moss C, Vader M (eds) Echolocation in bats and dolphins. University of Chicago Press, Chicago, IL, p 541-547

Fernandez-Juricic E, Campagna C, Enriquez V (1999) Vocal communication and individual variation in breeding South American sea lions. Behaviour 136:495-517

Ficken RW, Hailma JP (1974) Temporal pattern shifts to avoid acoustic interference in singing birds. Science 183:762-763

Gedamke J, Robinson SM (2010) Acoustic survey for marine mammal occurrence and distribution off East Antarctica $\left(30-80^{\circ}\right.$ E) in January-February 2006. Deep-Sea Res II 57: 968-981

Gerhardt HG (1994) The evolution of vocalization in frogs and toads. Annu Rev Ecol Syst 25:293-324

Gilbert JR, Erickson AW (1977) Distribution and abundance of seals in the pack ice of the Pacific sector of the Southern Ocean. In: Llano GA (ed) Adaptations within Antarctic ecosystems. Smithsonian Institution, Washington, DC, p 703-740

Green K, Burton HR (1988) Annual and diurnal variation in the underwater vocalizations of Weddell seals. Polar Biol 8:161-164

Greenacre MJ (1984) Theory and applications of correspondence analysis. Academic Press, London

Hadley GL, Rotella JJ, Garrott RA (2007) Evaluation of reproductive costs for Weddell seals in Erebus Bay, Antarctica. J Anim Ecol 76:448-458

> Halpern BS, Walbridge S, Selkoe KA, Kappel CV and others (2008) A global map of human impact on marine ecosystems. Science 319:948-952

Harcourt RG, Kingston JJ, Cameron MF, Waas JR, Hindell MA (2007) Paternity analysis shows experience, not age, enhances mating success in an aquatically mating pinniped the Weddell seal (Leptonychotes weddellii). Behav Ecol Sociobiol 61:643-652

Harcourt RG, Kingston JJ, Waas JR, Hindell MA (2008) Foraging while breeding: alternative mating strategies by male Weddell seals? Aquat Conserv Mar Freshw Ecosyst $17: 68-78$

> Hayes VJ, Terhune JM (2007) Underwater call sequences of Weddell seals (Leptonychotes weddellii) at the Vestvold Hills, Antarctica. Aquat Mamm 33:305-314

Heller KG, Von Helversen D (2004) Acoustic communication in phaneropterid bushcrickets: species-specific delay of female stridulatory response and matching male sensory time window. Behav Ecol Sociobiol 18:189-198

Insley SJ, Phillips AV, Charrier I (2003) A review of social recognition in pinnipeds. Aquat Mamm 29:181-201

Kaufman GW, Siniff DB, Reichle R (1975) Colony behavior of Weddell seals, Leptonychotes weddellii, at Hutton Cliffs, Antarctica. Rapp P-V Réun Cons Int Expl Mer 169:228-246

Kindermann L, Boebel O, Bornemann H, Burkhardt E and others (2008) A Perennial Acoustic Observatory in the Antarctic Ocean, Computational bioacoustics for assess- ing biodiversity. Bundesamt Naturschutz Skr 234:15-28

King JE (1969) Some aspects of the anatomy of the Ross seal, Ommatophoca rossii (Pinnipedia: Phocidae). British Antarctic Survey Scientific Reports No. 63, London

Klinck H (2008) Automated passive acoustic detection, localization and identification of leopard seals. PhD dissertation, University of Trier

Klinck H, Mellinger DK, Klinck K, Hager J, Kindermann L, Boebel O (2010) Underwater calls of the crabeater seal (Lobodon carcinophaga). J Acoustic Soc Am 128:474-479

Koenig-Langlo G, Herber A (1996) The meteorological data of the Neumayer Station (Antarctica) for 1992, 1993, and 1994. Reports on Polar and Marine Research 187, Alfred Wegener Institute, Bremerhaven

Kooyman GL (1975) A comparison between day and night diving in the Weddell seal. J Mammal 56:563-574

Krebs JR, Davies NB (1993) An introduction to behavioral ecology, 3rd edn. Blackwell Science, Oxford

Kunnasranta W, Hyvarinen H, Sorjonen J (1996) Underwater vocalizations of Ladoga ringed seals (Phoca hispida ladogensis Nordq) in summertime. Mar Mamm Sci 12:611-618

Laiolo P (2010) The emerging significance of bioacoustics in animal species conservation. Biol Conserv 143:1635-1645

Lake S, Wotherspoon S, Burton H (2005) Spatial utilisation of fast-ice by Weddell seals Leptonychotes weddellii during winter. Ecography 28:295-306

Latimer W, Broughton WB (1984) Acoustic interference in bush crickets; a factor in the evolution of singing insects? J Nat Hist 18:599-616

Learmonth JA, Macleod CD, Santos MB, Pierce GJ, Crick HQP, Robinson RA (2006) Potential effects of climate change on marine mammals. Oceanogr Mar Biol Annu Rev 44:431-464

Lugg DJ (1966) Annual cycle of the Weddell seal in the Vestfold Hills, Antarctica. J Mammal 47:317-322

Marimuthu G, Rajan S, Chandrashekaran MK (1981) Social entrainment in the flight activity of the microchiropteran bat Hipposideros speoris. Behav Ecol Sociobiol 8:147-150

> McCreery L, Thomas JA (2009) Acoustic analysis of underwater vocalizations from crabeater seals (Lobodon carcinophaga): not so monotonous. Aquat Mamm 35:490-501

Moors HB, Terhune JM (2004) Repetition patterns in Weddell seal (Leptonychotes weddellii) underwater multiple element calls. J Acoust Soc Am 116:1261-1270

> Mossbridge JA, Thomas JA (1999) An acoustic niche for Antarctic killer whale and leopard seal sounds. Mar Mamm Sci 15:1351-1357

> Murphy EJ, Watkins JL, Trathan PN, Reid K and others (2007) Spatial and temporal operation of the Scotia Sea ecosystem: a review of large-scale links in a krill centered food web. Philos Trans R Soc Lond B Biol Sci 362:113-148

Oetelaar ML, Terhune JM, Burton HR (2003) Can the sex of a Weddell seal (Leptonychotes weddellii) be identified by its surface call? Aquat Mamm 29:261-267

> Pahl BC, Terhune JM, Burton HR (1997) Repertoire and geographic variation in underwater vocalizations of Weddell seals (Leptonychotes weddellii, Pinnipedia: Phocidae) at the Vestfold Hills, Antarctica. Aust J Zool 45:171-187

Perry EA, Terhune JM (1999) Variation in harp seal (Pagophilus groenlandicus) underwater vocalizations among three breeding locations. J Zool 45:171-178

Plötz J (1986) Summer diet of Weddell seals (Leptonychotes weddellii) in the Eastern and Southern Weddell Sea, Antarctica. Polar Biol 6:97-102

Read AF, Weary DM (1992) The evolution of bird song: comparative analyses. Philos Trans R Soc Lond B Biol Sci 338: 165-187 
Reijnders PJH, Plötz J, Zegers J, Gräfe M (1990) Breeding biology of Weddell seals (Leptonychotes weddellii) at Drescher Inlet, Riiser Larsen Ice Shelf, Antarctica. Polar Biol 10:301-306

Riedman M (1990) The pinnipeds. Seals, sea lions and walruses. University of California Press, Berkeley, CA

Rogers TL (2003) Factors influencing the acoustic behaviour of male phocid seals. Aquat Mamm 29:247-260

Rogers TL (2007) Age-related differences in the acoustic characteristics of male leopard seals, Hydrurga leptonyx. J Acoust Soc Am 122:596-605

Rogers TL, Bryden MM (1997) Density and haul-out behaviour of leopard seals (Hydrurga leptonyx) in Prydz Bay, Antarctica. Mar Mamm Sci 13:293-302

Rogers TL, Cato DH (2002) Individual variation in the acoustic behaviour of the adult male leopard seal, Hydrurga leptonyx. Behaviour 139:1267-1286

Rogers TL, Cato DH, Bryden MM (1995) Underwater vocal repertoire of the leopard seal (Hydrurga leptonyx) in Prydz Bay, Antarctica. In: Kastelein RA, Thomas JA, Nachtigall PE (eds) Sensory systems of aquatic mammals. De Spil Publishers, Woerden, p 223-236

- Rogers TL, Cato DH, Bryden MM (1996) Behavioral significance of underwater vocalizations of captive leopard seals, Hydrurga leptonyx. Mar Mamm Sci 12:414-427

Rouget PA, Terhune JM, Burton HR (2007) Weddell seal underwater calling rates during the winter and spring near Mawson Station, Antarctica. Mar Mamm Sci 23:508-523

Roy D, Borah B, Sarma A (1995) Analysis and significance of female reciprocal call in frogs. Curr Sci 69:265-270

Ryan MJ (1988) Constraints and patterns in the evolution of anuran acoustic communication. In: Fritzsch B, Ryan M, Wilczynski W, Hetherington T, Walkowiak W (eds) The evolution of the amphibian auditory system. John Wiley \& Sons, New York, NY, p 637-677

Sato K, Yasutaka T, Kudoh S, Naito Y (2003) Meteorological factors affecting the number of Weddell seals hauling out on the ice during the molting season at Syowa Station, East Antarctica. Polar Biosci 16:98-103

Searcy WA, Andersson M (1986) Sexual selection and the evolution of bird song. Annu Rev Ecol Syst 17:507-533

Seibert AM (2007) The Ross seal and its underwater vocalizations. MSc thesis, University of Munich

Serrano A (2001) New underwater and aerial vocalizations of captive harp seals (Pagophilus groenlandicus). Can J Fish Aquat Sci 79:75-81

Serrano A, Miller EH (2000) How vocal are harp seals (Pagophilus groenlandicus)? A captive study of seasonal and diel patterns. Aquat Mamm 26:253-259

Serrano A, Terhune JM (2002) Antimasking aspects of harp seal (Pagophilus groenlandicus) underwater vocalizations. J Acoust Soc Am 112:3083-3090

Shaughnessy PD, Kerry KR (1989) Crabeater seals, Lobodon carcinophagus, during the breeding season: observations on five groups near Enderby Land, Antarctica. Mar Mamm Sci 5:68-77

Siniff DB, Bengtson JL (1977) Observations and hypotheses concerning the interactions among crabeater seals and leopard seals and killer whales. J Mammal 58:414-416

Siniff DB, Stone S (1985) The role of the leopard seal in the trophodynamics of the Antarctic marine ecosystem. In: Siegfried WR, Condy PR, Laws RM (eds) Antarctic nutrient cycles and food webs. Springer Verlag, Berlin, p 498-515

Siniff DB, Stirling I, Bengtson JL, Reichle RA (1979) Social and reproductive behavior of crabeater seals (Lobodon carcinophagus) during the austral spring. Can J Zool 57: 2243-2255
Siniff DB, Garrot RA, Rotella JJ, Fraser WR, Ainley DG (2008) Projecting the effects of environmental change on Antarctic seals. Antarct Sci 20:425-435

Slabbekoorn H (2004) Singing in the wild: the ecology of birdsong. In: Marler P, Slabbekoorn H (eds) Nature's music: the science of birdsong. Academic Press/Elsevier, San Diego, CA, p 178-205

Southall BL, Bowles AE, Ellison WT, Finneran JJ and others (2007) Marine mammal noise exposure criteria: initial scientific recommendations. Aquat Mamm 33:411-414

Southwell C (2005) Diving behaviour of two Ross seals off east Antarctica. Wildl Res 32:63-65

Southwell C, Kerry K, Ensor P, Woehler EJ, Rogers T (2003) The timing of pupping by pack-ice seals in East-Antarctica. Polar Biol 26:648-652

> Southwell CJ, Paxton CGM, Borchers DL, Boveng PL, Nordøy ES, Blix AS, De La Mare WK (2008) Estimating population status under conditions of uncertainty: the Ross seal in East Antarctica. Antarct Sci 20:123-133

Stacey RM (2006) Airborne and underwater vocalizations of the Antarctic Ross seal (Ommatophoca rossii). MSc thesis, Western Illinois University, Moline, IL

Staicer CA, Spector DA, Horn AG (1996) The dawn chorus and other diel patterns of acoustic signalling. In: Kroodsma DE, Miller EH (eds) Ecology and evolution of acoustic communication in birds. Cornell University Press, Ithaca, NY, p 426-453

Stirling I (1969) Ecology of the Weddell seal in McMurdo Sound, Antarctica. Ecology 50:573-586

> Stirling I, Siniff DB (1979) Underwater vocalizations of leopard seals (Hydrurga leptonyx) and crabeater seals (Lobodon carcinophagus) near the South Shetland Islands, Antarctica. Can J Zool 57:1244-1248

Stirling I, Thomas JA (2003) Relationships between underwater vocalizations and mating systems in phocid seals. Aquat Mamm 29:227-246

Sueur J (2002) Cicada acoustic communication: potential sound partitioning in a multi-species community from Mexico (Hemiptera: Cicadomorpha: Cicadidae). Biol J Linn Soc 75:379-394

> Tedman RA, Bryden MM (1979) Cow-pup behaviour of the Weddell seal, Leptonychotes weddellii (Pinnipedia), in McMurdo Sound, Antarctica. Aust Wildl Res 6:19-37

Terhune JM, Dell'Apa A (2006) Stereotyped calling patterns of a male Weddell seal (Leptonychotes weddellii). Aquat Mamm 32:175-181

Terhune JM, Burton H, Green K (1994) Weddell seal in-air call sequences made with closed mouth. Polar Biol 14: $117-122$

Testa W (1994) Over-winter movements and diving behavior of female Weddell seals (Leptonychotes weddellii) in the Southwestern Ross Sea, Antarctica. Can J Zool 72: 1700-1710

Testa JW, Oehlert G, Ainley DJ, Bengtson JL, Siniff DB, Laws RM, Rounsevell D (1991) Temporal variability in Antarctic marine ecosystems: periodic fluctuations in the phocid seals. Can J Fish Aquat Sci 48:631-639

Thomas JA (2002) Ross seal, Ommatophoca rossii. In: Perrin WF, Wursig B, Thewissen JGM (eds) Encyclopedia of marine mammals. Academic Press, San Diego, CA, p 1053-1055

Thomas JA, DeMaster DP (1982) An acoustic technique for determining diurnal activities in leopard (Hydrurga leptonyx) and crabeater (Lobodon carcinophagus) seal. Can J Zool 60:2028-2031

Thomas JA, Golladay CL (1995) Geographic variation in leopard seal (Hydrurga leptonyx) underwater vocalizations. 
In: Kastelein RA, Thomas JA, Nachtigall PE (eds) Sensory systems of aquatic mammals. De Spil Publishers, Woerden, p 201-222

Thomas JA, Kuechle VB (1982) Quantitative analysis of Weddell seal (Leptonychotes weddelli) underwater vocalizations at McMurdo Sound, Antarctica. J Acoust Soc Am 72:1730-1738

Thomas JA, Stirling I (1983) Geographic variation in the underwater vocalizations of Weddell seals (Leptonychotes weddelli) from Palmer Peninsula and McMurdo Sound, Antarctica. Can J Zool 61:2203-2212

Thomas J, DeMaster D, Stone S, Andriashek D (1980) Observations of a newborn Ross seal pup (Ommatophoca rossii) near the Antarctic peninsula. Can J Zool 58:2156-2158

Thomas JA, Zinnel KC, Ferm LM (1983) Analysis of Weddell seal (Leptonychotes weddellii) vocalizations using underwater playbacks. Can J Zool 61:1448-1456

Thomas JA, Puddicombe RA, George M, Lewis D (1988) Variations in underwater vocalisations of Weddell seals (Leptonychotes weddellii) at the Vestvold Hills as a measure of breeding population discreteness. Hydrobiologia 165: 279-284

Trillo PA, Vehrencamp SL (2005) Song types and their structural features are associated with specific contexts in the banded wren. Anim Behav 70:921-935

Tripovich JS, Charrier I, Rogers TL, Canfield R, Arnould JPY (2008) Acoustic features involved in neighbour-stranger vocal recognition in male Australian fur seals. Behav Processes 79:74-80

Van Opzeeland IC (2010) Acoustic ecology of marine mammals in polar oceans. PhD thesis, University of Bremen

Van Opzeeland IC, Kindermann L, Boebel O, Van Parijs SM (2008) Insights into the acoustic behaviour of polar pin-

Editorial responsibility: Hans Heinrich Janssen, Oldendorf/Luhe, Germany nipeds - current knowledge and emerging techniques of study. In: Weber EA, Krause LH (eds) Animal behaviournew research. Nova Science Publishers, Hauppage, NY, p 133-161

- Van Parijs SM (2003) Aquatic mating in pinnipeds: a review. Aquat Mamm 29:214-226

- Van Parijs SM, Thompson PM, Tollit DJ, Mackay A (1997) Distribution and activity of male harbour seals during the mating season. Anim Behav 54:35-43

Van Parijs SM, Hastie GD, Thompson PM (1999) Geographical variation in temporal and spatial vocalization patterns of male harbour seals in the mating season. Anim Behav 58:1231-1239

> Van Parijs SM, Kovacs KM, Lydersen C (2001) Spatial and temporal distribution of vocalising male bearded sealsimplications for male mating strategies. Behaviour 138: 905-922

> Van Parijs SM, Lydersen C, Kovacs KM (2003) Vocalizations and movements suggest alternative mating tactics in male bearded seals. Anim Behav 65:273-283

> Van Parijs SM, Lydersen C, Kovacs KM (2004) Effects of ice cover on the behavioural patterns of aquatic mating male bearded seals. Anim Behav 68:89-96

Wartzok D, Elsner R, Stone H, Kelly BP, Davis RW (1992) Under-ice movements and the sensory basis of hole finding by ringed and Weddell seals. Can $J$ Zool 70 : 1712-1721

Watkins WA, Ray GC (1985) In-air and underwater sounds of the Ross seal, Ommatophoca rossi. J Acoust Soc Am 77: $1598-1600$

Watkins WA, Schevill WE (1968) Underwater playback of their own sounds to Leptonychotes (Weddell seals). J Mammal 49:287-296

Submitted: July 27, 2009; Accepted: May 31, 2010

Proofs received from author(s): August 27, 2010 